\title{
Proposta de Aprimoramento do Ensaio de Ação de Calor e Choque Térmico na NBR 15575
}

\author{
João Heitzmann Fontenelle \\ Claudio Vicente Mitidieri Filho \\ Adriana Camargo de Brito \\ Cristina Kanaciro \\ Luciana Alves Oliveira \\ Fúlvio Vittorino
}

\section{O Ensaio de Ação de Calor e Choque Térmico}

O ensaio de Ação de Calor e Choque Térmico - ACCT, previsto na NBR 15575-4 (ABNT, 2013), é um método de avaliação de desempenho a ser considerado no fator de "Durabilidade" dos Sistemas de Vedação Vertical - SVVE - de uma habitação, sendo um dos poucos previstos no conjunto de requisitos relativos a esse fator, que é aplicável a qualquer sistema de fachada, independentemente dos seus materiais constituintes e do projeto da fachada. Observa-se que, nessa norma, há também referências a outros ensaios específicos para a avaliação de durabilidade, como o de corrosão e de exposição aos raios UV, que se destinam, respectivamente, a paredes e sistemas constituídos por componentes metálicos e por materiais orgânicos. Além do ensaio de ACCT, deve-se levar em conta os agentes de degradação mais agressivos para cada tipo de material empregado nos SVVE de uma edificação, detalhando-se parâmetros e métodos de análise específicos, como tem ocorrido nas Diretrizes de Avaliação Técnica elaboradas no âmbito do SiNAT. Essas outras ações, todavia, não são consideradas neste capítulo. 
O ensaio de ACCT foi concebido com o intuito de avaliar o efeito do aquecimento e do subsequente resfriamento brusco da fachada, como ocorre em dias verão, quando, após uma exposição prolongada à radiação solar, ela é resfriada por uma chuva de verão. Esse ensaio vem sendo utilizado desde o final da década de 1970 e início da década de 1980 e tem sido eficaz para detectar alguns problemas sistemáticos que poderiam ocorrer em edificações. Evidentemente, quando foi incorporado às avaliaçôes técnicas no Brasil, há praticamente 40 anos, o estado da arte dos sistemas de fachadas era bem diferente do atual. Também eram mais restritas as possibilidades de controle e automação do ensaio. Com o procedimento de ensaio apresentado na NBR 15575-4 (ABNT, 2013), era possível identificar problemas, por exemplo, de concepção de fachadas, que geravam uma fissuração sistemática ou que causavam falência de sistemas de juntas ou de revestimentos.

A partir da década de 2000, com a intensificação das atividades avaliação de desempenho de diversos sistemas construtivos com conceitos fortemente inovadores pelas diversas Instituiçôes Técnicas de Avaliação ITA's, integrantes do Sistema Nacional de Avaliação Técnica de Sistemas Inovadores e Convencionais - SiNAT, passou-se a perceber a necessidade de aprimoramento de alguns aspectos do método de ensaio, considerando: as dimensóes do corpo de prova, em particular seu comprimento; a necessidade de restrição à livre movimentação do corpo de prova (confinamentos laterais); as temperaturas limites do ensaio, em razão da capacidade térmica do elemento construtivo; a temperatura e a vazão da água para fazer o resfriamento brusco do elemento; a velocidade de aquecimento do corpo de prova; a duração dos patamares de temperatura; e o número de ciclos.

Neste capítulo, são apresentadas análises e discussões acerca da adequação de vários aspectos do método de ensaio atualmente em vigor e da possibilidade de aprimoramentos, para que, em uma futura revisão da NBR 15575-4 (ABNT, 2013), esse método possa ser também revisto e atualizado.

\section{Comportamento Higrotérmico de um SVVE}

Durante a vida útil de um edifício, o SVVE permanece exposto ao clima do local, estando sujeito a variaçóes de temperatura e de umidade em ciclos com diferentes períodos de ocorrência, tais como: os mais longos, com 
a alternância de características climáticas das estaçôes ao longo do ano; os diários, relativos à transição do período mais quente, durante o dia, para o mais frio, durante a noite; ou períodos muito curtos em que as variaçóes podem ocorrer de forma brusca, como o efeito do resfriamento instantâneo de uma chuva de veráo sobre uma parede previamente aquecida pelo sol.

Essas variaçôes das condições ambientais desencadeiam fluxos de calor e de água através dos componentes do SVVE, que resultam em gradientes de temperatura e de umidade ao longo do sistema de vedação. Tal situação, por sua vez, provoca alteraçóes volumétricas (tanto dilatação como contração) nesses componentes, gerando tensôes que podem ultrapassar as máximas toleráveis pelos materiais constituintes e resultar em fissuras no sistema de vedação.

Cada tipo de ciclo de variação das condiçóes de exposição ambientais pode proporcionar tensóes que atuam de diferentes formas e intensidades sobre o SVVE. Isso ocorre de forma distinta entre elementos pesados de capacidade e resistência térmicas significativamente diferentes, como as alvenarias e os elementos leves, ilustrados na Figura 1. Essas diferentes propriedades térmicas dos elementos de vedação resultarão em fluxos de calor e perfis internos de temperatura, ao longo da seção do SVVE, para uma mesma diferença de temperatura entre suas faces, como ilustrado na Figura 2.

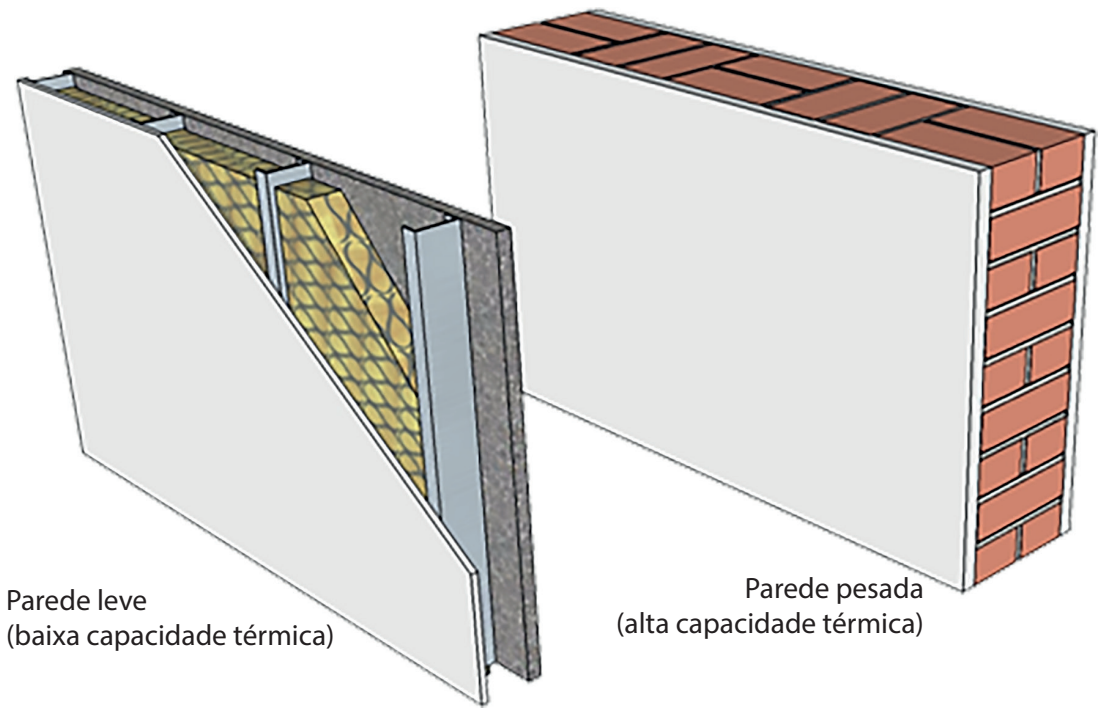

Figura 1. Exemplos de parede leve e pesada. Ilustração: Adriana C. de Brito. 


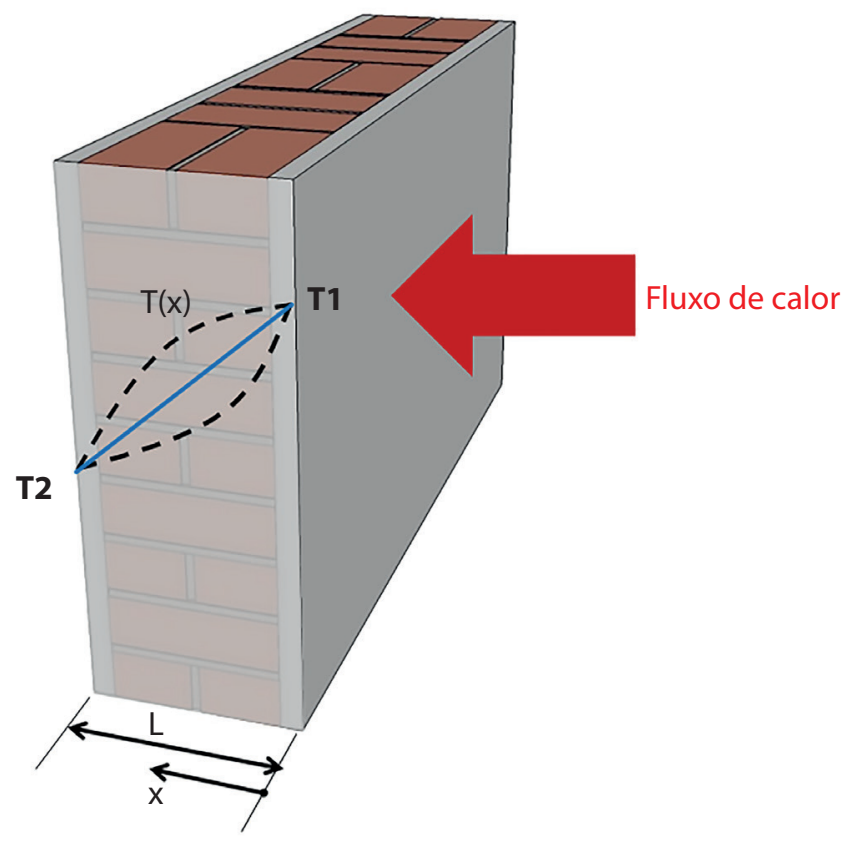

Figura 2. Exemplos de distribuição de temperatura e fluxo de calor por condução através de uma parede plana, desenho baseado em Kreith e Bohn (2003). Ilustração: Adriana C. de Brito.

Em linhas gerais, mantendo a mesma resistência e capacidade térmica de um SVVE constituído por material homogêneo, quanto mais rápida for a variação da temperatura de uma face externa, maior será a inclinação da curva de declínio da temperatura à medida que se afasta da face aquecida em direção à face interna da vedação. Também, em linhas gerais, pode-se dizer que quanto maior for a resistência térmica do SVVE, mais rápida se dará a elevação da temperatura superficial da sua face externa.

Mesmo em uma situação em que não há variação na quantidade total de água de uma parede, a simples variação de sua temperatura também afetará a distribuição teor de umidade contida nos poros dos materiais constituintes dos SVVE. Nestes casos, à medida que um SVVE se aquece, altera-se o próprio diâmetro dos poros, a pressão capilar, além das energias das ligaçôes entre a água e moléculas higroscópicas que podem estar presentes nos materiais e, decorrentemente, a umidade relativa no interior dos poros.

Entretanto, as deformaçóes e os deslocamentos resultantes, tanto nas condiçóes de exposição natural como no ensaio de ACCT, são proporcionados pela variação conjunta de temperatura e de umidade. Não é possível 
dizer, de forma generalizável, qual é o fenômeno preponderante, uma vez que há expansão quando se dá o aumento de temperatura, e retração quando ocorre a perda de água.

De fato, há determinados produtos, como as placas à base de cimento, nas quais as variaçóes decorrentes da alteração de umidade podem ser mais significativas que as variaçóes devido à mudança de temperatura. A variação conjunta da temperatura e a da umidade é um fenômeno complexo, que não será detalhado de modo aprofundado neste trabalho.

Contudo, é conveniente salientar que a maioria dos materiais utilizados para a produção de vedaçóes possui poros relativamente pequenos, o que torna lento o transporte de água em seu interior e reduzida a intensidade do movimento do líquido da superfície para o interior, quando se empregam sistemas de pintura de baixa permeabilidade. Nestes casos, pode-se atribuir a deformação verificada nos instantes em que o choque térmico ocorre ao fato de ser predominantemente resultante da variação da dilatação térmica, fator estudado com maior ênfase neste trabalho.

\section{Tensões Decorrentes do Gradiente de Temperatura Durante o Choque Térmico}

A velocidade da variação de temperatura da face exterior de um SVVE é um fator determinante para a transferência de calor por condução para o interior dos materiais e, consequentemente, para o estabelecimento do perfil do gradiente de temperatura ao longo da seção da vedação. Esse perfil de temperatura, por sua vez, será o principal causador de deformaçóes por dilatação térmica, que gerarão tensôes no corpo. Quando o estabelecimento desse gradiente de temperaturas se dá de forma lenta, há a possibilidade de que as dilataçóes térmicas ocorram de forma suave, promovendo uma redistribuição dessas tensôes, fazendo com que não se chegue a exceder o limite de ruptura.

Uma chuva de verão que atinge uma parede previamente aquecida pela radiação solar incidente em sua superfície é um dos fatores que proporcionam a variação abrupta da temperatura da face externa da parede em comparação com a temperatura da face interna ou de seu núcleo. Como resultado, tem-se uma contração térmica da superfície, enquanto as camadas mais internas do SVVE permanecem aquecidas e dilatadas, condição que impóe restriçóes ao processo de contração da superfície e gera tensôes. Assim, o choque térmico ocorre no momento de declínio da temperatura da fachada. Os parâmetros da chuva que resfria a parede, tais como a temperatura e a vazão da água que escorre sobre a face do SVVE, podem alterar a velocidade da transição 
da temperatura, alterando o gradiente de temperatura ao longo da seção da parede e, consequentemente, as intensidades das tensóes proporcionadas por essa variação de temperatura.

Partindo da observação de um ensaio de ACCT feito com uma parede maciça de material homogêneo, propóe-se um modelo simplificado da distribuição do gradiente de temperatura ao longo da seção de um SVVE, durante o fenômeno do choque térmico. Consideraram-se as alteraçóes de valores verificadas nas faces do corpo de prova, tais como a temperatura da face externa, a temperatura da face interna e os deslocamentos transversais a essas faces.

No interior de um SVVE maciço de material homogêneo (admitido essa forma simplificada para facilitar a discussão do tema), o gradiente de temperatura ao longo da seçáo da parede antes da incidência da chuva pode ser representado tal como se indica na Figura 3a. A inclinação da curva de temperatura pode variar conforme a intensidade da radiação que incidiu em sua face, das propriedades térmicas dos materiais ou tempo de aquecimento. Quando a chuva principia e atinge a face externa da parede, um fluxo do calor na seção da vedação analisada se inicia a partir do ponto em que a temperatura apresenta o seu maior valor e se desloca em direção à face externa, enquanto outro fluxo continua ocorrendo em direção à face interna, como apresentado na Figura 3b. À medida que o tempo passa, o pico de temperatura interna diminui e, ao mesmo tempo, desloca-se em sentido à face interna. Assim, temperatura da face externa diminui, enquanto a temperatura da face interna continua aumentando (Figura 3c). Esse pico de temperatura interna irá reduzir continuamente. Se as camadas mais internas do SVVE não tiverem elevada resistência térmica, o pico de temperatura continuará se deslocando em direção à face interna, para, a partir desse momento, iniciar a redução da temperatura da face interior (Figura 3d).

Como já citado, as tensôes geradas nesse processo são predominantemente proporcionadas pela dilatação térmica, visto que o modelo considerado foi constituído por um material com baixa percolação ou absorção de água, com baixa variação por efeito de umidade. Considerandose um plano vertical o ponto em que a temperatura da seçáo da parede apresenta o seu maior valor (Figura $4 \mathrm{a}$ e $4 \mathrm{~b}$ ), verifica-se a existência de dois segmentos de paredes paralelas: o segmento de parede "A" e o segmento de parede "B", ligados entre si. Cada um deles com espessuras diferentes e variáveis ao longo do tempo, conforme o pico de temperatura se desloca, mas com inclinaçóes das respectivas curvas de temperatura opostas uma em relação à outra (Figura 4 b). 
Proposta de Aprimoramento do Ensaio de Ação de Calor e Choque Térmico... Cap. 6
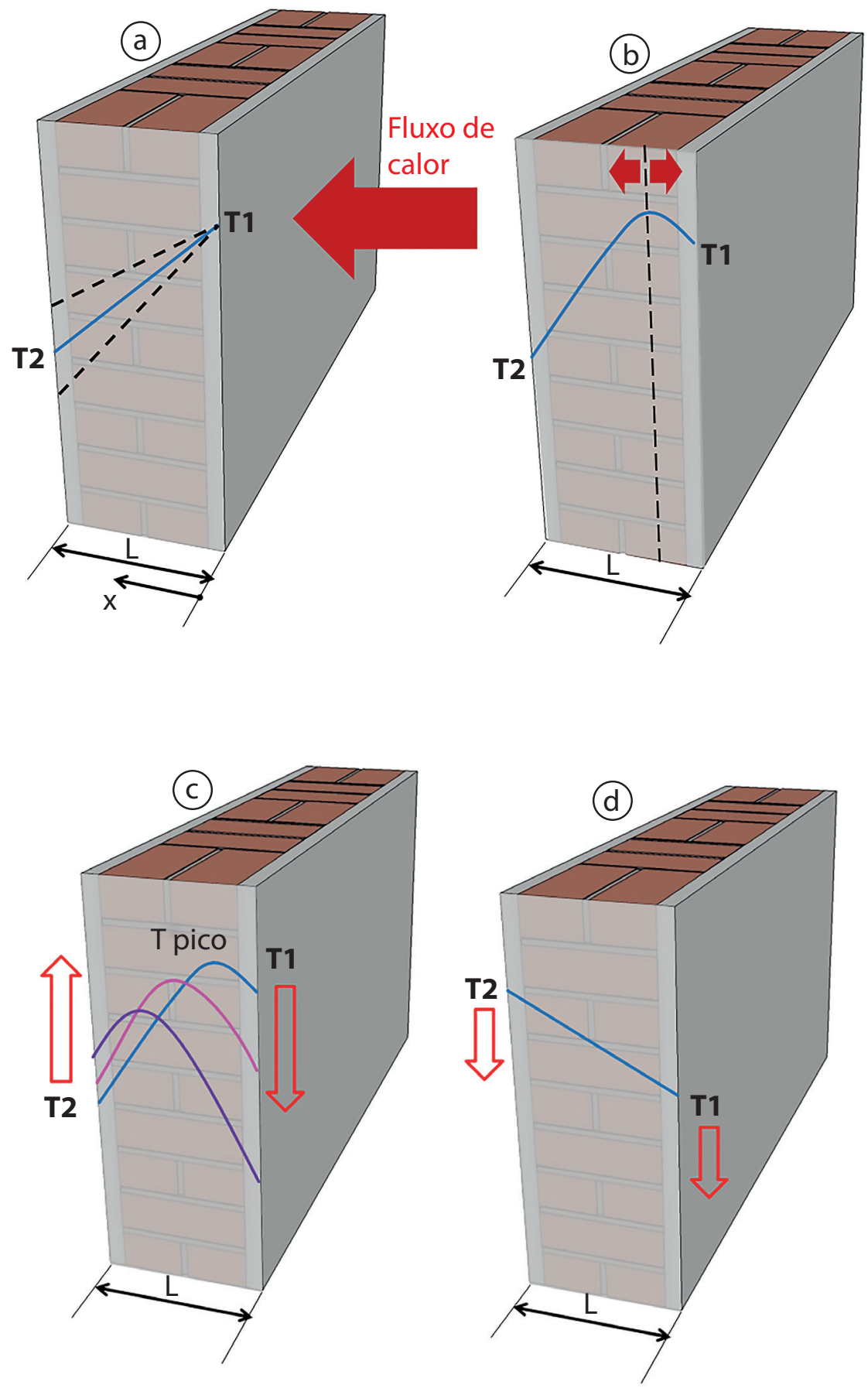

Figura 3. Hipótese de modelo de variação do gradiente térmico na seção da parede, desenho baseado em Kreith e Bohn (2003). Ilustração: Adriana C. de Brito. 
Avaliação de Desempenho de Tecnologias Construtivas Inovadoras:

Conforto Ambiental, Durabilidade e Pós-Ocupação
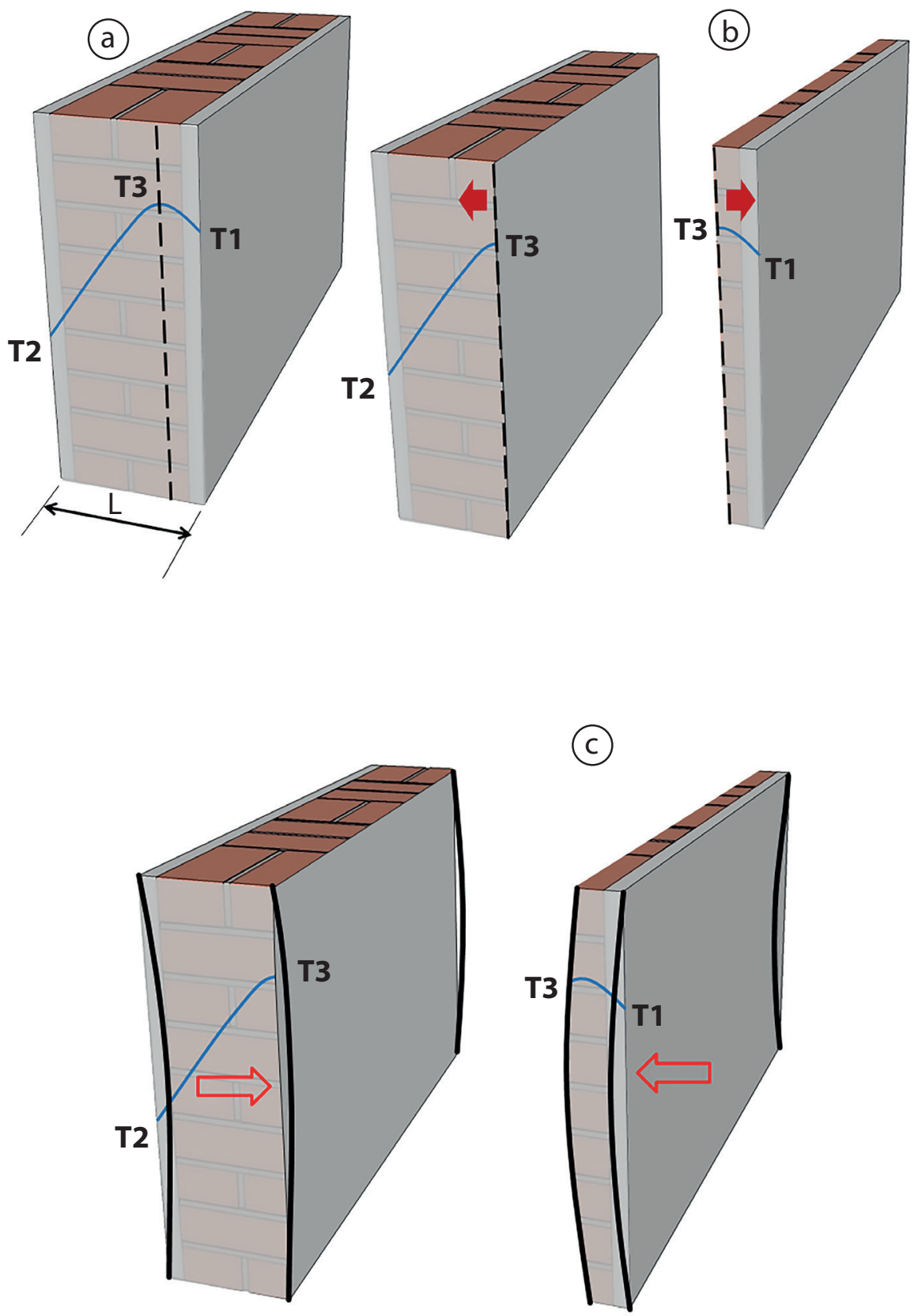

(C)

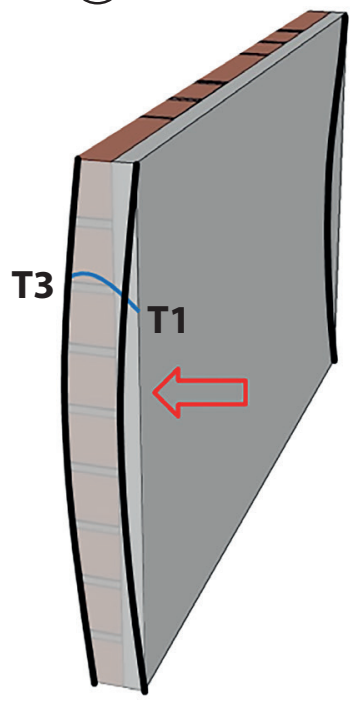

Figura 4. Hipótese de modelo de variação do gradiente térmico na seção da parede, desenho baseado em Kreith e Bohn (2003). Ilustração: Adriana C. de Brito. 
Analisando-se a tendência de deformação de cada um dos segmentos de parede separadamente, percebe-se que o sentido de deslocamento de cada uma delas será oposto ao da outra. Enquanto a regiáo central do segmento de parede "A", com a face externa do SSVE, desloca-se em sentido à face interna, o segmento de parede " $\mathrm{B}$ " apresenta o deslocamento no sentido oposto (Figura 4c). Tais ocorrências geram tensóes no alinhamento do plano imaginário entre essas paredes. Como esse plano desloca-se pela seção, à medida que se resfria a face externa da parede, seu efeito também se desloca ao longo dessa seção. Quanto maior for a variação da temperatura em cada lado, maiores serão as tensôes. Como os picos de temperatura na seção transversal da parede apresentam seu maior valor nos momentos iniciais do choque térmico, a magnitude das forças atuantes também é maior no início do processo de resfriamento, reduzindo sua intensidade com o passar do tempo.

Em razão das variaçóes dessas tensões, o ciclo de variação de temperatura em um curto espaço de tempo, ou seja, o choque térmico, é considerado um dos agentes de agressividade mais representativos para avaliar se um SVVE tem o potencial de suportar as tensôes decorrentes da ação dos agentes climáticos ao longo de sua vida útil, principalmente, tratando-se de um sistema inovador.

Essas tensôes se distribuem pelos corpos dos SVVE, através da ação e reação dos elementos adjacentes que constituem a vedação, até se depararem com sistemas apropriados que possam absorvê-las, ou pontos falhos com alguma deficiência de coesão. Caso encontrem juntas de dilatação flexíveis, por exemplo, as tensôes serão absorvidas por sua deformação. Por outro lado, caso se deparem com uma falha de aderência entre componentes, as tensôes podem ser aliviadas pela ocorrência de fissuras ou descolamentos.

\section{O Ensaio de Choque Térmico Segundo a NBR 15575 (ABNT, 2013)}

\subsection{Considerações Sobre o Ensaio de ACCT}

O ensaio de ACCT é um ensaio acelerado de laboratório, ou seja, tem como objetivo acelerar o processo de envelhecimento da parede para, deste modo, possibilitar a verificação, em um período reduzido de tempo, dos efeitos que a variação térmica pode proporcionar a um SVVE. Por meio desse ensaio, procura-se verificar a eventual ocorrência de danos ou falhas 
que poderão comprometer o desempenho da parede de fachada ao longo do tempo, além de limitar os deslocamentos da parede de fachada.

A aceleração do processo de envelhecimento em laboratório pode ocorrer por dois processos, podendo ser usados separada ou concomitantemente. $\mathrm{O}$ primeiro consiste em aumentar a frequência da ocorrência dos agentes de agressividade mais críticos, com as mesmas intensidades que são verificadas em situação de uso. Nesse processo, o foco do controle concentra-se em reproduzir a mesma intensidade da agressão, por meio do controle dos parâmetros dos agentes de agressividade, assim como o reestabelecimento de uma situaçáo inicial comum do corpo de prova, com características similares às que se verificam em situação de uso.

O segundo processo consiste em aumentar a intensidade dos agentes de agressão em relação à intensidade verificada em situaçáo de uso. Nesse caso, é importante efetuar uma análise prévia dos efeitos desses ensaios acelerados feitos em laboratório em comparação com os efeitos do envelhecimento natural, pois é necessário limitar a intensidade dos agentes de agressividade para se evitar a ocorrência de fenômenos de degradação secundários, ou seja, degradaçôes que não se verificam durante o envelhecimento em exposição natural.

A aceleração do ensaio de ACCT baseia-se no processo de aumento da frequência de ocorrência de agentes de agressividade mais críticos, mantendo a intensidade da agressão muito próxima da intensidade com que ocorrem em situação de uso mais agressiva. Tal opção pode ser justificada pela abrangência de tecnologias que se pretende avaliar por meio desse ensaio, com vedaçóes constituídas de diversos materiais e que, portanto, podem apresentar diferentes comportamentos em relação à variação na intensidade dos agentes de agressão. Adota-se como pressuposto para a realização do ensaio de ACCT que, se um SVVE for capaz de resistir por certo número de ciclos às maiores tensóes possíveis de serem induzidas no corpo do seu sistema, será capaz de resistir aos ciclos de tensóes de menores magnitudes que costumam ocorrer com uma maior frequência, no decorrer da sua vida útil.

\subsection{Breve Histórico da Origem do Ensaio e sua Evolução até Chegar ao Anexo E da NBR 15575-4 (ABNT, 2013)}

O método atual de ensaio de ACCT tem mantido sua redação, seus parâmetros de ensaios e ilustraçóes inalterados nos últimos 36 anos. A 
primeira publicação brasileira que faz referência ao método desse ensaio foi em um documento técnico elaborado pelo IPT para o extinto BNH, Banco Nacional da Habitaçáo, no final dos anos de 1970 e início dos anos de 1980 (IPT, 1981). Esta foi a primeira vez que se desenvolveu um documento técnico, visando fixar diretrizes para avaliação de desempenho de habitaçóes térreas unifamiliares no Brasil, incluindo o aspecto de durabilidade, além de outros assuntos. Em 1995 o texto inicial sofreu adaptaçóes, em razão de um projeto de pesquisa realizado com apoio da FINEP. Um dos resultados desse projeto foi a publicação, em 1998, de um texto para discussão dos critérios e métodos que poderiam ser adotados no Brasil para avaliação de habitaçôes. A referida discussão foi conduzida pela antiga Secretaria de Habitação e Secretaria de Planejamento Urbano do Ministério de Planejamento e Orçamento. Tal publicação foi intitulada "Critérios mínimos de desempenho para habitações térreas de interesse social” (IPT, 1998).

Os parâmetros adotados nos critérios e no método de ensaio, desde o final de 1970, foram obtidos em documentos estrangeiros da época e adaptados em razão das condições de exposição no Brasil e da experiência da equipe do IPT naquele período. Os documentos estrangeiros mais importantes vinham da França, em especial do Centre Scientifique et Technique du Bâtiment - CSTB; da Bélgica, do Centre Scientifique et Technique de la Construction - CSTC; dos EUA, da Operação Breakthrough; do Reino Unido, do Building Research Establishment - BRE, dentre outros, como documentos elaborados no âmbito do PNUD, Programa das Naçôes Unidas para o Desenvolvimento.

Anteriormente à instauração da CE - Desempenho de edificações, no início, no início da década de 2000, houve um trabalho, coordenado pelo COBRACON, que organizou o primeiro texto base da NBR 15575 (ABNT, 2013). A primeira publicação da NBR 15575 foi em 2008 e, após revista, foi publicada novamente em 19 de fevereiro de 2013, passando a ser válida a partir de 19 de julho de 2013.

\subsection{O Método de Ensaio Atual de ACCT}

Em geral, os ensaios de ACCT baseiam-se no princípio de elevar a temperatura da face de um corpo de prova até uma temperatura específica, denominada aqui de temperatura de patamar, manter a face submetida à análise nessa temperatura por um determinado período de tempo e depois 
resfriá-la bruscamente pela aspersão de água. A diferença entre os métodos, verificados em normas e documentos técnicos, está na definição do valor da temperatura, do tempo de permanência nesse patamar, no controle das variáveis de resfriamento, na definição de intervalos entre ciclos e no número de ciclos. Os parâmetros básicos especificados pelo anexo E da NBR 15575-4 (ABNT, 2013) são apresentados na Tabela 1 .

Tabela 1. Parâmetros básicos do método de ACCT - Anexo E da NBR 15575-4 (ABNT, 2013).

\begin{tabular}{|c|c|}
\hline Parâmetro & Referência \\
\hline Largura* corpo de prova & $\geq 1,20 m \pm 0,20 m$ \\
\hline Altura do corpo de prova & $\begin{array}{c}\text { "parede acabada" } \\
\text { Em geral, pé direito típico }\end{array}$ \\
\hline Temperatura de patamar (Tp) & $(80 \pm 3)^{\circ} \mathrm{C}$ \\
\hline Tempo de permanência na Tp & 1 hora \\
\hline $\begin{array}{l}\text { Intervalo entre interrupção da } \\
\text { radiação e início resfriamento }\end{array}$ & Imediato \\
\hline Tempo de resfriamento & Não definido \\
\hline Condições para fim do resfriamento & Temperatura da face aquecida $=(20 \pm 5)^{\circ} \mathrm{C}$ \\
\hline Intervalo entre ciclos & Não definido \\
\hline Número de ciclos & 10 \\
\hline
\end{tabular}

* Também é adotado o termo comprimento do corpo de prova neste capítulo.

Nessa norma há informaçóes sobre controle dos parâmetros do ensaio, como o posicionamento dos cinco termopares em que serão verificadas as temperaturas. Além disso, o método determina que seja registrado o valor da flecha (deslocamento horizontal) que ocorre no centro da parede, transcorridos 45 minutos do início do tempo de patamar de temperatura e após o resfriamento do corpo de prova. Também deve ser feito o registro de degradaçôes que ocorrem ao longo do ensaio, especificando qual tipo de falha e em qual momento foi verificada.

\section{Aspectos do Ensaio de Ação de Calor e Choque Térmico a Serem Aprimorados}

O ensaio de ACCT pode contribuir, principalmente, para a avaliação da durabilidade de sistemas inovadores de vedaçóes verticais, permitindo identificar aqueles com comportamento inadequado, quando expostos 
ao clima. Nesse contexto, o termo "inovadores" compreende sistemas que não possuem normas técnicas específicas, ou seja, que não têm histórico significativo de obras concluídas, com edificações expostas aos vários climas do território brasileiro, por período relevante de tempo que possibilite identificar aspectos relativos à sua durabilidade.

Como em qualquer análise de desempenho, não se pode considerar somente o resultado obtido no ensaio de choque térmico para tirar conclusóes referentes à durabilidade de um componente. É sempre necessária a realização de análises complementares, considerando as reais condiçôes da fachada e do clima local. Com o ensaio de ACCT nos moldes atuais, tem sido observado que, quando há falhas no corpo de prova, é praticamente certo que tais falhas ocorrerão em situação normal de uso. O contrário, porém, não assegura, necessariamente, que não ocorrerão eventuais problemas em edificaçóes, havendo a necessidade de uma análise global do sistema para se ter maior segurança em seu uso.

O ensaio de ACCT tem sido utilizado por vários laboratórios e ITA's, e sofreu modificaçôes em algumas Diretrizes de Avaliação Técnica, fruto da experiência dessas Instituiçóes na avaliação de novas tecnologias, mais recentemente adotadas na construção de habitações. Essas modificaçôes são relativas ao comprimento do corpo de prova (2,40 m em vez de 1,20 m) e quanto às condiçôes de vinculação laterais. Buscou-se, também, em algumas Diretrizes, associar o ensaio de estanqueidade à água de paredes externas ao ensaio de ACCT, realizando o ensaio de estanqueidade antes e após o ensaio de ACCT.

Contudo, apesar dessa experiência acumulada, há necessidade do aprimoramento do ensaio de ACCT, a partir da revisão e complementação de alguns procedimentos. $\mathrm{Na}$ revisão aqui apresentada procurou-se considerar tudo o que é entendido como fundamental para se garantir a sua reprodutibilidade, ou seja, a capacidade das Instituiçôes realizarem o ensaio de uma maneira padronizada. Há variáveis no decorrer do ensaio que necessitam de um controle mais aprimorado e outras que precisam ser ajustadas ou complementadas, considerando-se a relação entre os fenômenos climáticos que se verificam em campo e os parâmetros para realização dos ensaios em laboratório. Do ponto de vista da análise dos resultados e do entendimento do comportamento dos produtos, na prática, é preciso considerar como esses agentes provocam a degradação dos SVVE. Esse 
entendimento é fundamental para que o referido ensaio seja um instrumento que auxilie o desenvolvimento tecnológico do setor da construção civil.

\subsection{Aspecto 1 - Temperaturas Superficiais Limites}

O limite superior da temperatura da face externa aplicada a todos os SVVE, denominado temperatura de patamar (Tp), é hoje de $80^{\circ} \mathrm{C} \pm 3^{\circ} \mathrm{C}$, independentemente do local onde ele será utilizado, da capacidade térmica, da resistência térmica e de cores de acabamento da parede.

Quando se ensaiam sistemas leves, com o uso de materiais isolantes térmicos posicionados proximamente à face exterior do SVVE, é natural atingir-se temperaturas superficiais mais elevadas do que em situaçóes em que se têm componentes de alta transmitância térmica, os quais podem conduzir o calor para o núcleo do SVVE e elevar a capacidade térmica do local onde esse calor pode ser armazenado, como os já ilustrados na Figura 1.

Isso significa que, ao se impor uma mesma temperatura para todos os corpos de prova, alguns deles serão expostos a condiçôes térmicas as quais jamais estarão sujeitos em condiçóes reais.

\subsection{Aspecto 2 - Taxa de Elevação da Temperatura Superficial}

Dependendo das características térmicas e físicas dos materiais que compóem o SVVE, é necessário fornecer quantidades significativamente diferentes de energia para que o componente atinja o valor da temperatura de patamar em tempos razoáveis. A título de exemplo, cita-se que, em ensaios realizados no Laboratório de Componentes e Sistemas Construtivos do IPT, mantendo-se a mesma taxa de aquecimento, um sistema construtivo composto por placas cimentícias com espessura de $1 \mathrm{~cm}$, levou 30 minutos para atingir a Tp, enquanto painéis monolíticos de concreto convencional, com $15 \mathrm{~cm}$ de espessura, demoraram 6 horas.

Conforme discutido na seção acerca do comportamento higrotérmico do SVVE, a alta velocidade de aquecimento de sua face resulta em uma variação mais acentuada ao longo da seção transversal do sistema, resultando em tensóes elevadas na parede, devido a diferenças da variação dimensional. Caso se pratique uma taxa de aquecimento muito elevada, pode-se gerar tensôes irreais na fase de aquecimento. É razoável considerar que as diferenças 
de tensôes geradas pela variação da taxa de aquecimento se verifiquem até o momento da vedação atingir a temperatura de patamar. Durante a fase de manutenção dessa temperatura, não deve ocorrer uma intensificação de tal situação.

Portanto, há necessidade de estabelecer parâmetros para a taxa de aquecimento da parede, de forma a se padronizar as condições de exposição a serem adotadas e de não gerar mecanismos de degradação fictícios, decorrentes apenas de questóes operacionais da realização do ensaio.

\subsection{Aspecto 3 - Controle dos Parâmetros do Fluxo de Água de Resfriamento}

É no processo de resfriamento que ocorre a maior taxa da variação da temperatura da parede, sendo necessário o estabelecimento do processo de controle para que cada ciclo de choque térmico proporcione solicitaçóes com intensidade semelhantes entre si e representativas da situação de exposição que for mais crítica na prática. Diferentemente do controle da taxa de elevação da temperatura, o controle, no momento do choque, da taxa de queda da temperatura superficial é muito difícil de ser executado.

Isso porque a curva do resfriamento depende da troca de calor por convecção entre a água que escoa e a face da parede que é banhada pela água da aspersão; e pelo calor conduzido a partir do interior dessa parede, acumulado ao longo da permanência na temperatura de patamar. Esse processo é determinado tanto pelas características térmicas do SVVE como pela rugosidade de sua superfície.

Pode-se abordar a situação de modo mais controlado a partir das variáveis que determinam a taxa de resfriamento do sistema, ou seja, a temperatura e a vazão da água que escorre sobre a face do elemento de vedação. A temperatura da água afeta diretamente a troca de calor convectiva entre a face da parede e o filme de água, enquanto a vazão da água altera tanto o coeficiente de troca como a taxa de transferência de calor.

A aspersão de água com temperatura mais elevada resultará em uma velocidade de redução da temperatura superficial mais branda do que a proporcionada por uma água mais fria. Por sua vez, uma vazáo menor implicará em um aquecimento mais rápido da água que escorre sobre a face, diminuindo a taxa de redução da temperatura da face. Nos dois casos, a 
variaçáo do gradiente de temperatura da seção da parede altera a intensidade das tensóes decorrentes desse gradiente e, consequentemente, a ação que o choque térmico proporciona ao SVVE ensaiado.

Ressalta-se que o método atual não especifica a duração do processo de resfriamento, mas limita a temperatura superficial, que pode variar em razão da temperatura da água. É possível que as condições para início de cada novo ciclo não sejam, necessariamente, as mesmas. Para se melhorar essa situação, pode-se fixar a duração do processo de resfriamento, fato que irá reduzir a variabilidade da quantidade total de energia térmica retirada.

\subsection{Aspecto 4 - Tolerâncias entre Valores de Temperaturas da Face da Parede (Diferenças entre Centro e Bordas)}

É pertinente uma redefinição da hierarquização e das tolerâncias entre diferenças de temperatura, entre o ponto central e os pontos periféricos do corpo de prova. O conceito de verificar a temperatura da face em cinco pontos, um central e quatro nos cantos diagonais, tem como princípio avaliar a homogeneidade do aquecimento entre a região que recebe mais radiação, a central, e as que são mais sujeitas a trocas de calor com o meio, como os cantos diagonais. Por outro lado, verifica-se na prática que, em alguns SVVE, a diferença entre a temperatura da região central e das bordas ultrapassa $o$ limite de $\pm 3^{\circ} \mathrm{C}$ em alguns momentos do ensaio.

Além disso, todos os pontos de controle dificilmente atingem a faixa de temperatura de tolerância simultaneamente, dificultando a determinação do início do tempo de temperatura de patamar.

\subsection{Aspecto 5 - Contenção Lateral dos Corpos de Prova}

$\mathrm{O}$ atual método de ensaio não prevê a utilização de restriçôes laterais nos corpos de prova, permitindo que eles dilatem-se livremente, sem sofrer esforços decorrentes da força de reação que restrições periféricas imporiam (Figura 5). Essa é uma situação que precisa ser investigada, pois, em condições reais, não é incomum os SVVE terem suas dilatações resistidas por elementos da edificação que não sofrem a mesma elevação de temperatura, como, por exemplo, pilares de muito maior capacidade térmica ou paredes internas em amarração. 


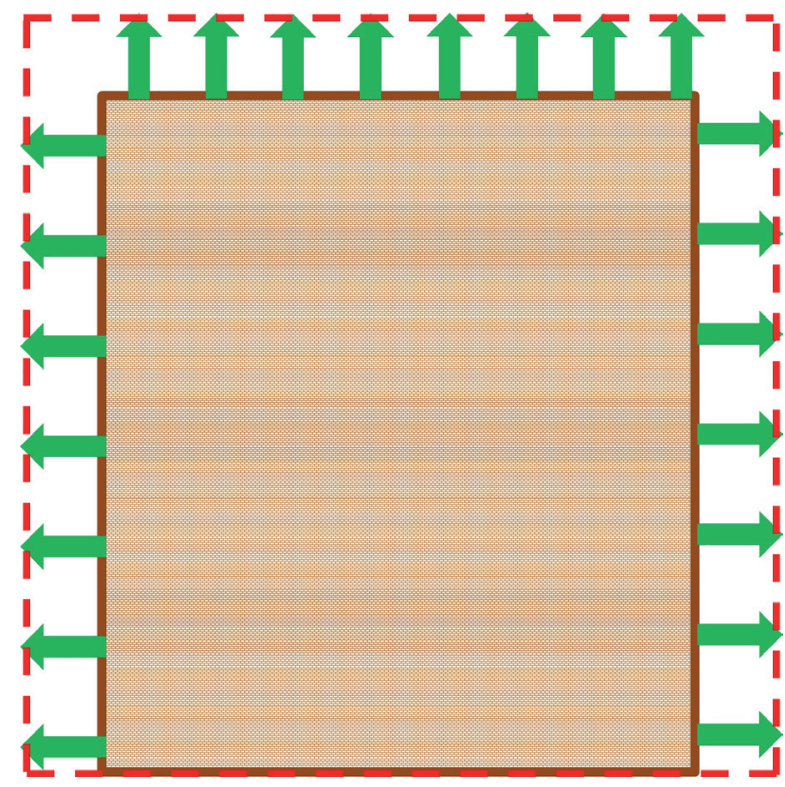

Figura 5. Esquema da variação do perímetro de um corpo de prova sem contenção lateral (FONTENELLE; MITIDIERI, 2016).

Para alguns SVVE constituídos por materiais que possuam dilataçóes relativamente pequenas por efeito da variação de umidade e temperatura, a contenção pode não ser um fator essencial. Entretanto, para outros sistemas, é possível que o corpo de prova possa apresentar comportamento diferente se vinculado, particularmente se os valores dos coeficientes de variação por efeito de umidade e temperatura forem elevados. Essa hipótese está baseada em observaçóes e análises, quando se comparam os resultados obtidos com vinculaçôes com os de situaçóes em que não há vínculos que impeçam movimentos verticais e horizontais no plano da parede ou do corpo de prova empregado no ensaio.

Contudo, a adoção de dispositivos rígidos de contenção lateral e de vínculos entre esses dispositivos e a borda lateral do corpo de prova podem também proporcionar condições de vinculação diferentes daquelas que seriam verificadas em situação de uso. A aplicação de dispositivos rígidos de contenção pode afetar a amplitude do deslocamento horizontal da parede. Tal deslocamento seria contido pelo vínculo do corpo de prova com o dispositivo de contenção lateral. 


\subsection{Aspecto 6 - Comprimento do Corpo de Prova}

O comprimento do corpo de prova pode proporcionar diferenças nos valores das intensidades das tensóes geradas nas paredes. Em paredes com painéis modulares, o tamanho do corpo de prova é relevante para avaliar se as juntas absorvem as deformaçóes específicas decorrentes dessas tensôes, sem que haja a ocorrência de falhas. Caso os corpos de prova sejam de 1,20 m, os efeitos podem ser menores, pois, no caso do emprego de juntas, haveria somente dois trechos de $60 \mathrm{~cm}$ de parede; se na prática, o módulo for de 1,20 $\mathrm{m}$, pode ocorrer uma deformação específica maior.

\section{Método de Geração de Aprimoramentos}

Para cada um dos aspectos apontados, foi adotado um método específico de abordagem, baseado em: análises de outros textos normativos internacionais que apresentam ensaios de ACCT; simulaçôes computacionais; e, principalmente, realização de ensaios exploratórios. Cada uma dessas abordagens está apresentada em seu respectivo estudo de aprimoramento.

\subsection{Aprimoramento 1 - Temperaturas Superficiais Limites}

Para a geração de aprimoramentos referentes aos valores limites da temperatura superficial dos componentes, foram feitos os seguintes procedimentos: revisão bibliográfica, que compreende, além da norma NBR 15575 (ABNT, 2013), outros documentos estrangeiros; e realização de simulaçóes computacionais da resposta térmica de uma edificação exposta a várias condiçôes climáticas, com o intuito de identificar valores típicos da temperatura de paredes externas, variando-se a capacidade térmica da parede.

\subsubsection{Revisão Bibliográfica}

Além na norma de desempenho [NBR 15575-4, (ABNT, 2013)] foram consultados documentos estrangeiros que abordam o fenômeno do choque térmico para a avaliação de SVVE, tais como: AS/NZS 2908-2: Cellulosecement products Part 2 - Flat sheets (AZ/NZS, 2000); ASTM C1185 (ASTM, 2008): Standard Methods for Sampling and Testing Non-Asbestos Fiber-Cement Flat Sheet, Roofing and Siding Shingles, and Clapboards, (ASTM, 2008); ETAG 004: Guideline for European techinical aproval of External Thermal 
Isulation Composite Systems with rendering (EOTA, 2008) e ISO 8336: Fibrecement flat sheets - Product specification and test metholds, (ISO, 2009).

A NBR 15575-4 (ABNT, 2013) estabelece o valor de $80{ }^{\circ} \mathrm{C}$ de temperatura superficial máxima para o ensaio de choque térmico de qualquer tipo de vedação vertical, seja uma parede de concreto (massa específica de $2400 \mathrm{~kg} / \mathrm{m}^{3}$ ) com espessura de $20 \mathrm{~cm}$, seja uma vedação em placa de OSB (massa específica da ordem de $400 \mathrm{~kg} / \mathrm{m}^{3}$ ), com espessura de $1 \mathrm{~cm}$.

Por outro lado, os métodos de ensaio internacionais determinam um valor limite para a temperatura superficial, com ordem de grandeza entre $(60 \pm 5)^{\circ} \mathrm{C} \mathrm{a}(70 \pm 5)^{\circ} \mathrm{C}$, em função do tipo de componente avaliado. As normas AS/NZS 2908-2 (AZ/NZS, 2000), ISO 8336 (ISO, 2009) e ASTM C1185 (ASTM, 2008) são aplicáveis a placas cimentícias, e a norma ETAG 004 (EOTA, 2008), a argamassas reforçadas sobre isolantes térmicos rígidos. Esses sistemas possuem uma espessura da ordem de $5 \mathrm{~mm}$ a $25 \mathrm{~mm}$, com massa específica entre $1200 \mathrm{~kg} / \mathrm{m}^{3}$ e $1800 \mathrm{~kg} / \mathrm{m}^{3}$. Por terem densidades próximas, para aquecer esses componentes durante o ensaio, é necessário fornecer a mesma ordem de grandeza de energia térmica, com exposição desses elementos em períodos de tempo próximos, o que náo acontece no caso da norma brasileira, a qual não se restringe a uma gama restrita de componentes.

Com base nas análises dos documentos, verificou-se que, no caso do ensaio de choque térmico presente na norma NBR 15575 (ABNT, 2013), é necessário estabelecer um valor limite para a temperatura da face externa em função da capacidade térmica do SVVE. Nesse sentido, poderiam ser agrupados componentes construtivos com a mesma ordem de grandeza de capacidade térmica, que seriam ensaiados a um determinado valor de temperatura superficial. Dessa forma, para ensaiar componentes dentro da mesma "família" de valores de capacidade térmica, a fim de alcançar os valores da temperatura superficial dessa "família", seriam necessárias quantidades semelhantes de energia, além de tempo de exposiçáo ao calor também similar.

\subsubsection{Simulações em Computador}

No intuito de estabelecer valores de referência da temperatura superficial de componentes para o ensaio de choque térmico, foram feitas simulações computacionais da resposta térmica de uma edificação com o 
programa EnergyPlus, a fim de identificar quais seriam os valores típicos da temperatura superficial de vários tipos de componentes, quando expostos a várias condições climáticas extremas.

Foram considerados SVVE com "capacidade térmica externa" CTe de 7 a $200 \mathrm{~kJ} /\left(\mathrm{m}^{2} . \mathrm{K}\right)$, conforme Tabela 2. A capacidade térmica dos componentes leva em conta a espessura, a massa específica e o calor específico das camadas de materiais, como indicado na norma NBR 15220 (ABNT, 2008). Para componentes com material isolante térmico, a capacidade térmica da envoltória externa do componente foi calculada levando em conta somente as camadas a partir desse material, voltadas para o ambiente externo. Esse procedimento foi adotado, pois, no contexto do ensaio de choque térmico, é relevante a capacidade térmica da porção da parede que está exposta ao clima. Essa forma de se calcular a capacidade térmica é diferente da utilizada no contexto da avaliação do desempenho térmico de habitações pelo método simplificado da norma NBR 15575 (ABNT, 2013), na qual é levada em consideração a capacidade térmica interna, que considera as camadas de material entre a face interna da parede e a camada de material isolante térmico.

Para situações típicas de exposição da edificação ao clima, selecionaram-se dados de um dia típico de verão da cidade de Porto Velho - RO, provenientes da NBR 15575 (ABNT, 2013), local que apresenta maior valor de radiação solar global em comparação com os dias típicos de outras cidades. Foram consideradas outras duas condições climáticas mais rigorosas: a que leva em consideração os dados de dias típicos de verão constantes nos arquivos climáticos do programa EnergyPlus para Porto Velho, com frequência de ocorrência de 5\%; e a delimitada a partir dos dados do dia típico de verão da cidade de Porto Velho, indicado na NBR 15575 (ABNT, 2013), considerando-se um valor da radiaçáo global incidente no plano horizontal significativamente maior que o valor indicado na referida norma. Nas três situaçóes analisadas, adotou-se velocidade do vento igual a zero, para se considerar uma condição crítica, na qual as trocas se dão por convecçáo natural, gerando assim a mais alta temperatura superficial da parede externa possível. Os dados climáticos da cidade são apresentados na Tabela 3.

1 Termo novo, proposto para diferenciar da "capacidade térmica", usualmente adotada para fins de avaliação de desempenho térmico. Considera-se, no caso do emprego de núcleos isolantes térmicos, apenas uma parte do elemento construtivo. 
Tabela 2. Capacidade térmica dos componentes da parede com camadas descritas a partir da face externa.

\begin{tabular}{|c|c|}
\hline SVVE & $\mathrm{CTe}\left[\mathrm{kJ} /\left(\mathrm{m}^{2} . \mathrm{K}\right)\right]$ \\
\hline $0,5 \mathrm{~mm}$ de aço, $5 \mathrm{~cm}$ de Polisocianurato e $0,5 \mathrm{~mm}$ de aço & 7 \\
\hline $\begin{array}{l}\text { Chapa cimentícia com espessura de } 1 \mathrm{~cm} \text {, lã de rocha com } 5 \mathrm{~cm} \text { de } \\
\text { espessura, placa de gesso acartonado com 1,25 cm de espessura }\end{array}$ & 29 \\
\hline $\begin{array}{l}2 \mathrm{~cm} \text { de argamassa reforçada, } 20 \mathrm{~cm} \text { de poliestireno expandido e } \\
2,0 \mathrm{~cm} \text { de argamassa reforçada }\end{array}$ & 61 \\
\hline $\begin{array}{l}3 \mathrm{~cm} \text { de argamassa comum, } 6,5 \mathrm{~cm} \text { de EPS e } 3 \mathrm{~cm} \text { de argamassa } \\
\text { comum }\end{array}$ & 74 \\
\hline $\begin{array}{l}\text { Blocos cerâmicos vazados com dimensões } 9 \mathrm{~cm} \times 14 \mathrm{~cm} \times 19 \mathrm{~cm} \text {, } \\
\text { revestidos em ambas as faces com 1,5 cm de argamassa comum }\end{array}$ & 121 \\
\hline $\begin{array}{l}\text { Blocos vazados de concreto com dimensões } 14 \mathrm{~cm} \times 19 \mathrm{~cm} \times 39 \mathrm{~cm} \text {, } \\
\text { revestidos em ambas as faces com } 2 \mathrm{~cm} \text { de argamassa comum }\end{array}$ & 172 \\
\hline $\begin{array}{l}\text { Painel vazado de PVC com espessura de } 3 \mathrm{~mm} \text {, preenchido com } \\
\text { concreto comum com espessura de } 8 \mathrm{~cm}\end{array}$ & 199 \\
\hline Painel de concreto leve com espessura de $10 \mathrm{~cm}$ & 200 \\
\hline
\end{tabular}

Tabela 3. Dados climáticos da cidade de Porto Velho.

\begin{tabular}{lcccc}
\hline Fonte & $\begin{array}{c}\text { Temp. máxima } \\
\text { diária (verão) }\left({ }^{\circ} \mathbf{C}\right)\end{array}$ & $\begin{array}{c}\text { Amplitude } \\
\text { diária de } \\
\text { temp. }\left({ }^{\circ} \mathbf{C}\right)\end{array}$ & $\begin{array}{c}\text { Temp. } \\
\text { de bulbo } \\
\text { úmido }\left({ }^{\circ} \mathbf{C}\right)\end{array}$ & $\begin{array}{c}\text { Radiação solar } \\
\left(\mathbf{W h} / \mathbf{m}^{2}\right)\end{array}$ \\
\hline NBR 15575 & 34,8 & 12,5 & 26 & 6.666 \\
\hline USDOE & 35,4 & 10,4 & 25,6 & 7.059 \\
\hline $\begin{array}{l}\text { NBR 15575 C/ } \\
\text { maior radiação }\end{array}$ & 34,8 & 12,5 & 26 & 13.000 \\
\hline
\end{tabular}

As paredes externas foram simuladas voltadas à direção Oeste, com absortância à radiação solar de 0,3 a 0,9 , correspondendo desde cores claras até cores escuras e com sujidade. Com o objetivo de compor valores de referência para a temperatura da parede no ensaio de choque térmico, foram utilizados como referência os resultados obtidos em paredes com absortância de 0,5 (cor média) e 0,9 (cor muito escura) com o intuito de considerar, respectivamente, a sujidade de paredes claras e escuras em edificaçóes construídas. Nas Figuras 6 e 7, são apresentados os valores máximos das temperaturas superficiais obtidos, respectivamente, para paredes com cor média e cor escura (absortância de 0,5 e 0,9) em função da sua capacidade térmica externa, para os três dias típicos definidos. 
Avaliação de Desempenho de Tecnologias Construtivas Inovadoras:

Conforto Ambiental, Durabilidade e Pós-Ocupação

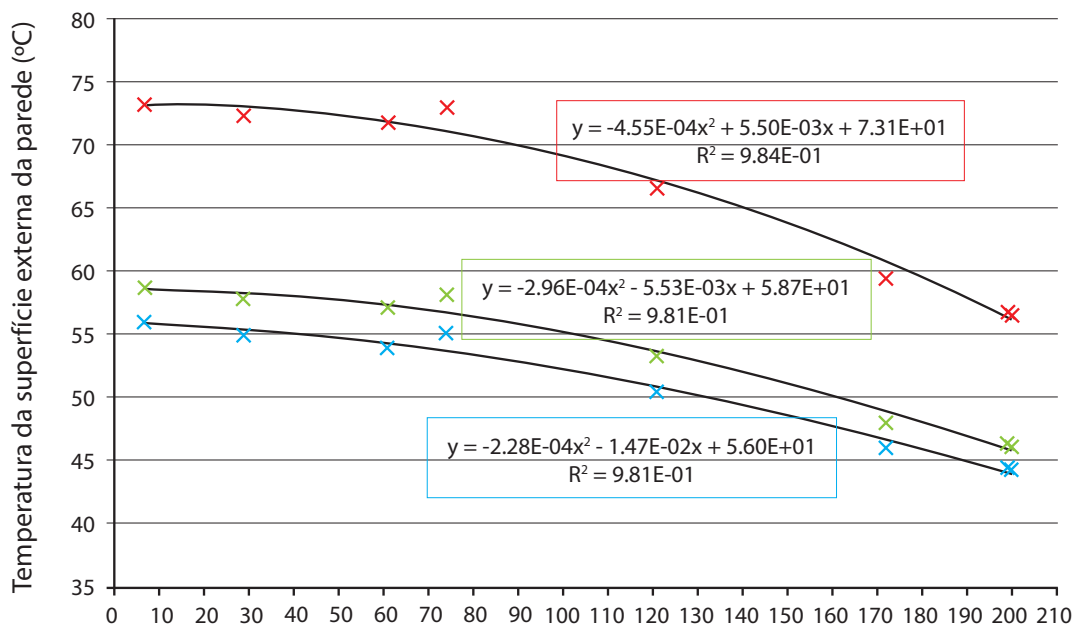

Capacidade térmica do SVVE $\left(\mathrm{kJ} / \mathrm{m}^{2} . \mathrm{K}\right)$

× NBR 15575 × NBR 15575 c/ Rad. Máx. Energy Plus × USDOE

Figura 6. Temperatura superficial máxima da face externa da parede em função da sua capacidade térmica para paredes com cores médias.

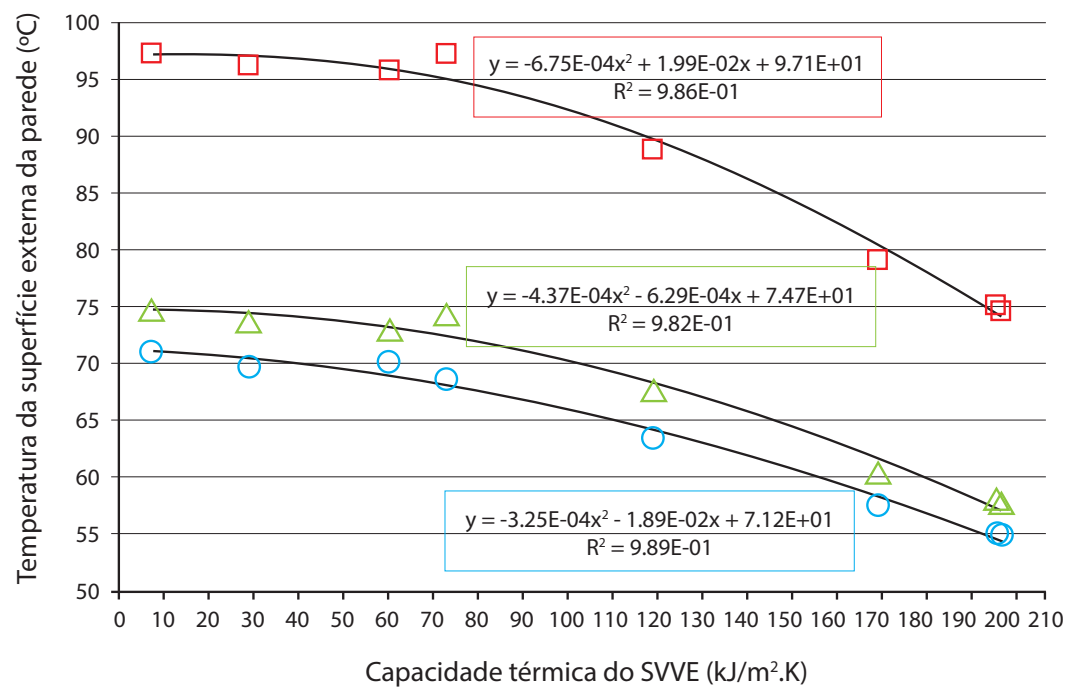

NBR 15575

NBR 15575 c/ Rad. Máx. Energy Plus

USDOE

Figura 7. Temperatura superficial máxima da face externa da parede em função da sua capacidade térmica para paredes com cores escuras. 


\subsection{Aprimoramento 2 - Taxa de Elevação da Temperatura Superficial}

O método adotado para a lacuna concernente à taxa de elevação da temperatura superficial foi a revisão bibliográfica comparativa e a análise da variação do gradiente de temperatura em ensaios já realizados. Dentre os documentos técnicos verificados, apenas a ETAG 004 (EOTA, 2008) especifica uma taxa máxima de elevação da temperatura superficial.

Observa-se que, o referido documento é o único que determina a realização da mediçáo direta da temperatura na face da parede, além da NBR 15575 (ABNT, 2013). Outros métodos de ensaio utilizam, para controlar a elevação de temperatura, um sensor de temperatura independente, instalado sobre uma superfície isolada termicamente e recoberto com tinta de alta absorção térmica, representando um corpo negro.

\subsection{Aprimoramento 3 - Controle dos Parâmetros do Fluxo de Água de Resfriamento}

O método aplicado para a lacuna referente ao controle dos parâmetros do fluxo de água de resfriamento foi o levantamento bibliográfico em normas, estudo de relatórios de ensaios anteriores e inspeção termográfica da superfície de corpos de prova, preparados especificamente para a presente pesquisa. Foi feito também levantamento com relação à temperatura da água de chuva no Brasil. Os parâmetros relacionados com a temperatura, vazão da água e tempo de aspersão são verificadas nos métodos de ensaio encontrados nos documentos técnicos pesquisados. Os valores encontram-se na Tabela 4

Tabela 4. Parâmetros aplicados à aspersão de água.

\begin{tabular}{cccc}
\hline Documento & Fluxo & Temp. $\left({ }^{\circ} \mathrm{C}\right)$ & Tempo \\
\hline ISO 8336 & $1 \mathrm{~L} /\left(\mathrm{m}^{2} \cdot \mathrm{min}\right)$ & - & $2 \mathrm{~h} 50 \mathrm{~min} \pm 5 \mathrm{~min}$ \\
\hline ASTM C1185 & $\approx 1 \mathrm{~L} /\left(\mathrm{m}^{2} \cdot \mathrm{min}\right)$ & $<30^{\circ} \mathrm{C}$ & $2 \mathrm{~h} 55 \mathrm{~min}$ \\
\hline ETAG 004 & $1 \mathrm{~L} /\left(\mathrm{m}^{2} \cdot \mathrm{min}\right)$ & $(15 \pm 5)^{\circ} \mathrm{C}$ & $1 \mathrm{~h}$ \\
\hline
\end{tabular}

A vazão indicada nesses documentos é da mesma ordem de grandeza, o que, contudo, não acontece com a temperatura e com o tempo de aspersão. O menor tempo de aspersão verificado foi de 1 hora, encontrado na ETAG 004 (EOTA, 2008). Apenas a ISO 8336 (ISO, 2009) não especifica a 
temperatura da água. No atual método previsto na NBR 15575-4 (ABNT, 2013), esses parâmetros não são contemplados.

\subsection{Aprimoramento 4 - Tolerâncias entre Valores das Temperaturas do Corpo de Prova (Bordas e Centro)}

O método considerado para a formulação da proposta baseou-se na pesquisa bibliográfica e na experiência de ensaios realizados. Os valores definidos nas normas técnicas pesquisadas estáo apresentados na Tabela 5 .

Tabela 5. Parâmetros aplicados às temperaturas do corpo de prova.

\begin{tabular}{ccc}
\hline Documento & Ponto central (Pc) & Pontos da borda \\
\hline ISO 8336 & $60^{\circ} \mathrm{C} \pm 3^{\circ} \mathrm{C}$ & $\mathrm{PC}{ }^{\circ} \mathrm{C} \pm 15^{\circ} \mathrm{C}$ \\
\hline ASTM C1185 & $60^{\circ} \mathrm{C} \pm 5^{\circ} \mathrm{C}$ & $60^{\circ} \mathrm{C} \pm 3^{\circ} \mathrm{C}$ \\
\hline ETAG 004 & $70^{\circ} \mathrm{C} \pm 5^{\circ} \mathrm{C}$ & - \\
\hline
\end{tabular}

As tolerâncias admitidas para a temperatura do ponto central variam entre $3^{\circ} \mathrm{C}$ e $5^{\circ} \mathrm{C}$. Entretanto, para as temperaturas dos pontos de borda, observam-se diferenças significativas entre os documentos analisados. Ressalta-se que o limite admitido para a diferença entre as temperaturas de borda e a temperatura do ponto central no caso da ISO 8336 (ISO, 2009) é bem alto, de $15^{\circ} \mathrm{C}$, situação que pode ser conseguida sem maiores esforços. $\mathrm{O}$ ponto central é sempre a referência para as temperaturas do corpo de prova, consideração de extrema razoabilidade, dado que o ponto central representa a média de toda a regiâo, é o local da medição dos deslocamentos, e os pontos periféricos representam uma medida da homogeneidade da distribuição de temperaturas.

\subsection{Aprimoramento 5 - Contenção Lateral dos Corpos de Provas}

Para a geração de aprimoramentos referentes à aplicação de contenção lateral dos corpos de provas, foram feitos os seguintes procedimentos: revisão bibliográfica e realização de ensaios exploratórios.

Em nenhuma das normas mencionadas foram verificadas referências explícitas que abordem a adoção de um dispositivo específico para contenção lateral dos corpos de prova, simulando a continuidade da parede. Existem 
referências genéricas, tal como verificada na ASTM C1185 (ASTM, 2008), as quais mencionam que a montagem de uma estrutura de teste deve ser feita de acordo com as recomendaçôes do fabricante e deve também simular a rigidez de uma instalação em canteiro. Entretanto, encontram-se na literatura artigos recentes que descrevem divergências entre os resultados obtidos no ensaio acelerado em laboratório e o verificado pelo acompanhamento de um envelhecimento natural, justificando o estudo de tais dispositivos para a contenção lateral e explicitando as eventuais influências nos resultados.

Em Oliveira et al. (2014), descreve-se a comparação de alguns ensaios realizados com e sem contenção lateral, contrastando os resultados obtidos com o envelhecimento verificado em um protótipo exposto em situação de uso. O sistema construtivo avaliado é constituído por steel frame com placas cimentícias na face externa. Apesar de ainda não haver uma definição clara do tipo de contenção lateral, os autores concluem que a realização do ensaio com alguma restrição à expansão demonstrou maior similaridade com a degradação verificada em situação de envelhecimento natural. Em Lorenzi (2015), verifica-se a proposta de aplicar o confinamento das extremidades do corpo de prova como procedimento para simular a situação de contorno mais semelhante às condiçôes reais de uso. A autora propôe uma contenção feita por um quadro de apoio, tal como um pórtico metálico, ajustável nas laterais e na parte superior, de modo a restringir uma possível expansão de seus limites. Em Fontenelle e Mitidieri (2016), são descritas as características teóricas de restrição de movimentação apresentada por um sistema de contenção lateral para simular a situação de uso.

Nos ensaios exploratórios conduzidos neste projeto de pesquisa, procurou-se avaliar também o efeito de uma contenção lateral proporcionada pela continuidade do corpo de prova, além da área sujeita diretamente à açáo do calor e do choque térmico. Tal contenção é feita pelo prolongamento das bordas laterais da parede para além dos limites da área de aquecimento por pelo menos metade do comprimento da área aquecida de cada lado. Essa continuidade contribui para conter a expansão ou retração da regiáo aquecida, na direção horizontal no plano da parede, considerando a simulação da situação de uso. Nessas condiçôes, são empregadas no corpo de prova todos os dispositivos, detalhes e simulação de vínculos, como previstos para execução em obra. 


\subsubsection{Ensaios em Paredes de Alvenaria de Blocos Cerâmicos}

Os ensaios exploratórios foram realizados inicialmente em dois corpos de prova de 2,40 m de comprimento, constituídos de alvenaria de blocos cerâmicos com reboco na face externa (Foto 1). No ensaio do $\mathrm{CP} 1$, considerou-se uma área de aquecimento com comprimento de 1,20 $\mathrm{m}$ e altura igual ao seu pé direito, alinhando-se o eixo do painel radiante, também com 1,20 m de comprimento, ao eixo do corpo de prova (Foto 2). Decorre disso que a continuidade da parede que não foi aquecida tem 60 $\mathrm{cm}$ de cada lado da zona de aquecimento, aproximadamente; esses trechos laterais, contínuos, poderão representar uma contenção ao deslocamento e à deformação da parede. Foram monitorados os deslocamentos laterais e os deslocamentos transversais na meia altura da parede. As mediçóes dos deslocamentos transversais foram feitos também no eixo do corpo de prova e a $30 \mathrm{~cm}$ das bordas laterais, para representarem o eixo da parte da parede que corresponderia ao elemento de continuidade (Foto 3), além da medida no centro da parede, para efeito de verificação do critério de desempenho quanto ao deslocamento máximo admitido.

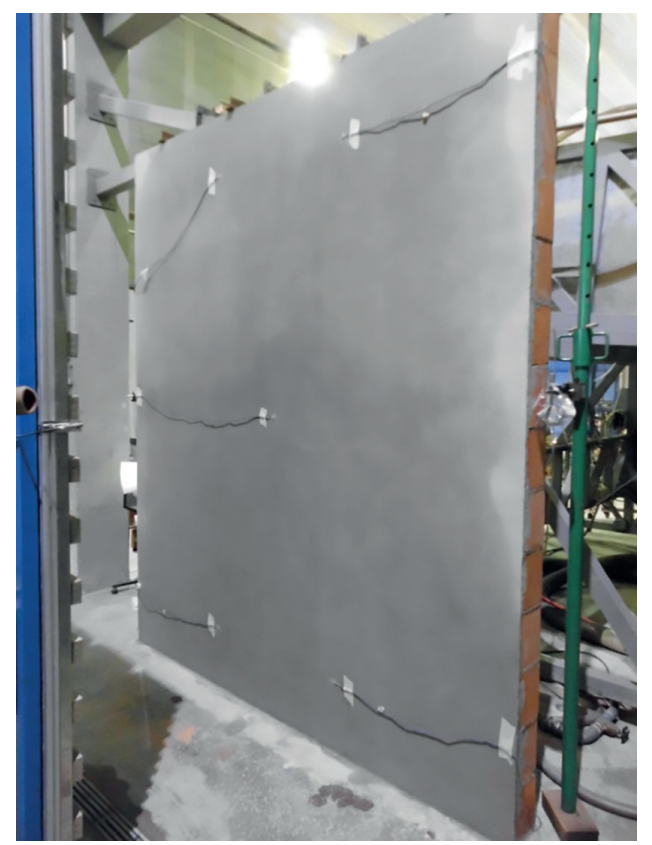

Foto 1. Face do CP1 com termopares. 


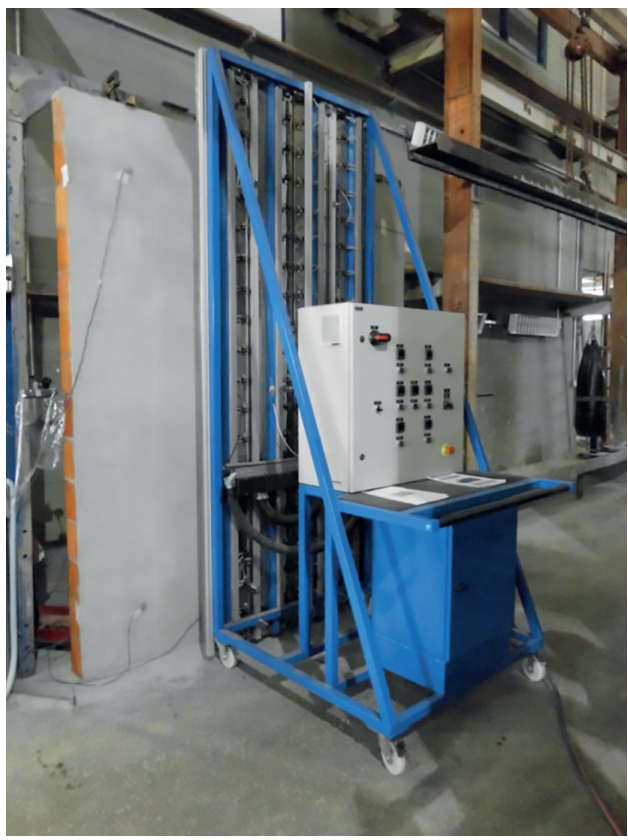

Foto 2. CP1 - Posicionamento do painel radiante.

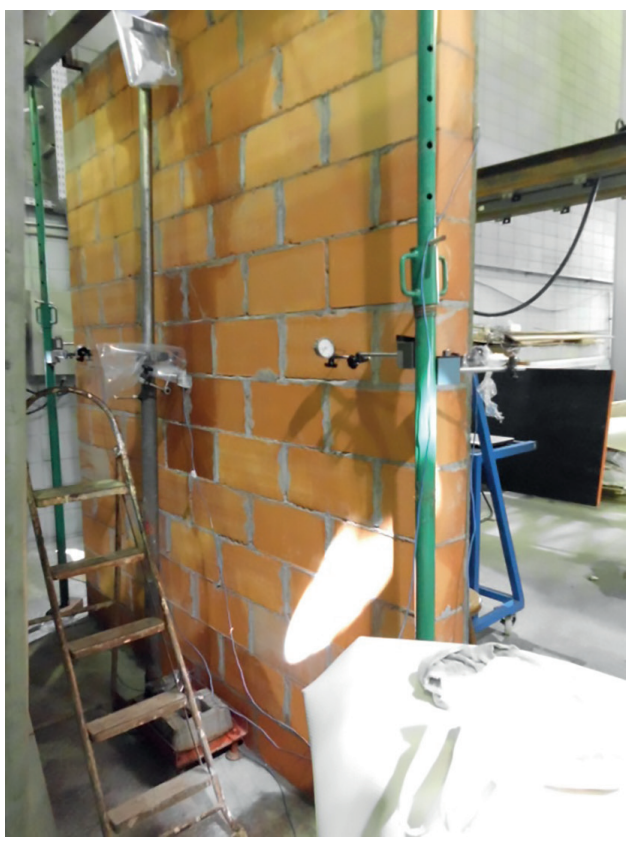

Foto 3. CP1 - Face posterior com localização dos relógios comparadores. 


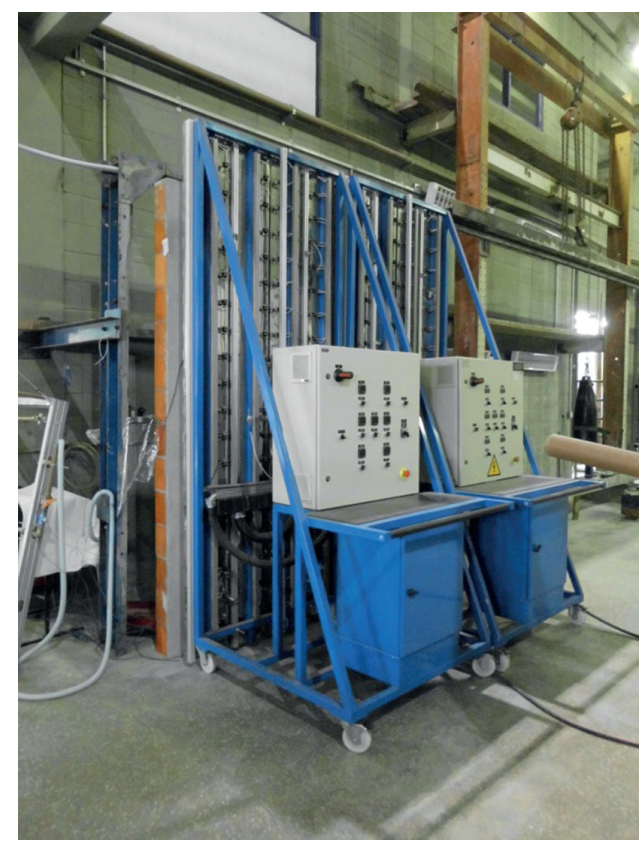

Foto 4. CP2 - Posicionamento dos painéis radiantes para aquecimento de 2,40 $\mathrm{m}$ de largura.

O CP2 foi submetido ao ensaio de ACCT aquecendo-se toda a sua face externa, ou seja, 2,40 $\mathrm{m}$ de comprimento, por meio de dois painéis radiantes com comprimento de 1,20 m, cada um (Foto 4). Nesse ensaio, não foram considerados elementos específicos de contenção lateral, nem a continuidade da parede fora da região de aquecimento. Os registros de deslocamentos foram feitos nas bordas laterais, a meia altura da parede. Os relógios comparadores da parte posterior foram posicionados no eixo do corpo de prova e a $60 \mathrm{~cm}$ da borda lateral, também a meia altura da parede.

Com base em uma análise termográfica feita no decorrer desses ensaios, constatou-se no CP1 que o calor transmitido da área aquecida para a continuidade da parede se distribui por uma largura de aproximadamente 80 $\mathrm{mm}$, além da faixa de 1,20 m (Fotos 5 e 6). 


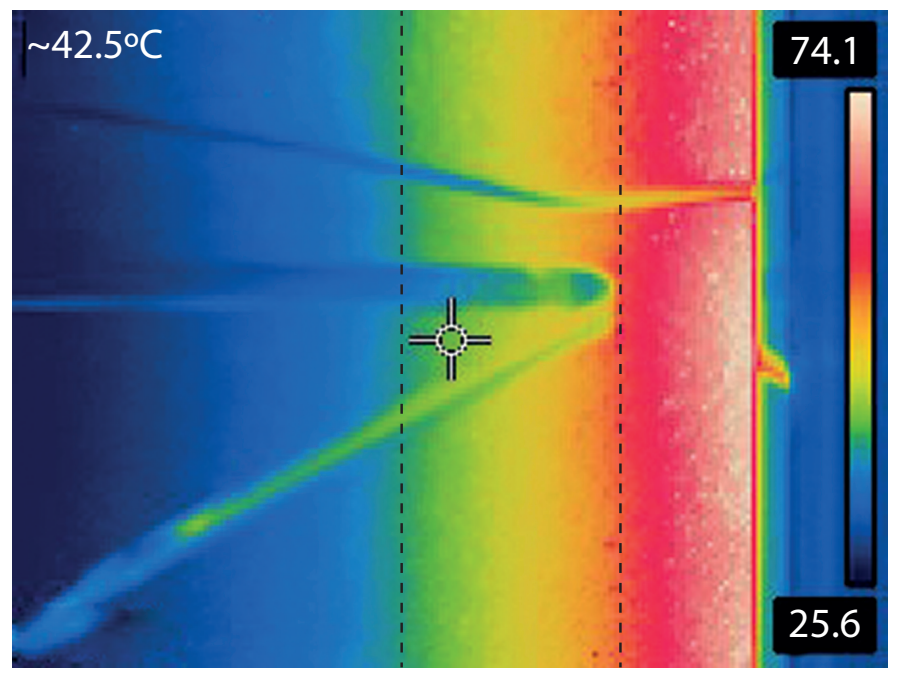

Foto 5. Imagem termográfica da continuidade, além da largura de aquecimento (CP1).

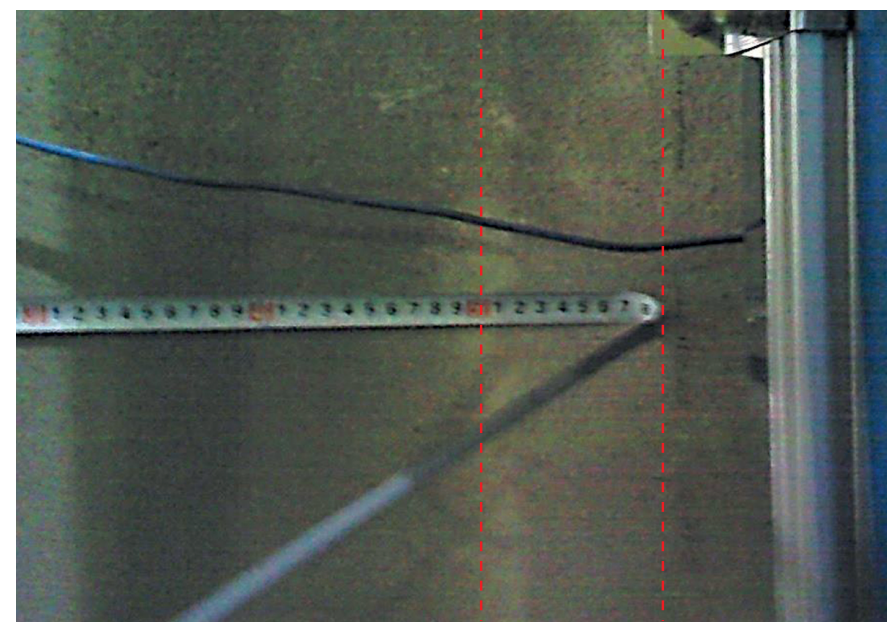

Foto 6. Dimensão relativa à distribuição do calor, além de 1,20 m (CP1).

Houve ocorrência de fissuras horizontais no corpo de prova CP1, localizadas nas extremidades do corpo de prova, apenas na zona de continuidade da parede, ou seja, fora da área de aquecimento (Fotos 9 e 10). 


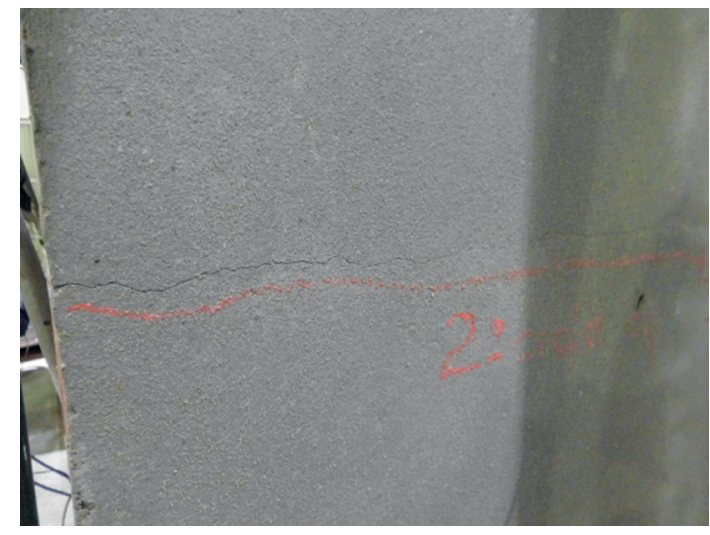

Foto 9. Fissura na lateral esquerda do CP1.

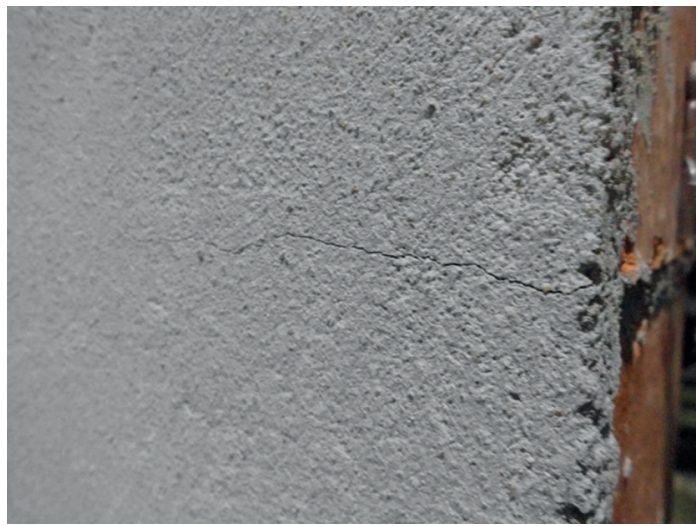

Foto 10. Fissura na lateral direita do $\mathrm{CP} 1$.

Os valores médios dos deslocamentos laterais foram de $0,72 \mathrm{~mm}$ para a parede com continuidade lateral, aquecida com painel radiante de 1,20 $\mathrm{m}$, e de 1,23 $\mathrm{mm}$ para a parede aquecida completamente. Considerandose a base das medidas como o comprimento do corpo de prova, de 2,40 $\mathrm{m}$, obtém-se uma dilatação unitária de $0,30 \mathrm{~mm} / \mathrm{m}$ para a parede de 2,40 $\mathrm{m}$ de comprimento, e aquecimento na regiáo central em torno de $1,20 \mathrm{~m}(0,08 \mathrm{~m}+0,08 \mathrm{~m}$ para o painel radiante com $1,20 \mathrm{~m})$. Para a parede totalmente aquecida, nos $2,40 \mathrm{~m}$, a dilataçáo linear foi de $0,51 \mathrm{~mm} / \mathrm{m}$. Isso significa que a continuidade do elemento, de certa forma, promoveu uma contenção lateral, haja vista que, se a movimentação observada pudesse ser 
considerada apenas em relação à base de aquecimento, de 1,28 m, teríamos uma movimentação específica do $\mathrm{CP} 1$ próxima à do $\mathrm{CP} 2$.

Outro aspecto observado foi o deslocamento horizontal. No patamar de aquecimento, enquanto o corpo de prova com continuidade da parede, CP1, teve um deslocamento médio de $2,45 \mathrm{~mm}$, o corpo de prova sem continuidade, CP2, teve um deslocamento de $1,97 \mathrm{~mm}$. Por outro lado, na fase de resfriamento, o deslocamento voltado para a face interna foi menor na parede com continuidade em relação à parede sem continuidade. A amplitude total da variação, ou seja, a soma dos módulos dos deslocamentos foi de 2,85 $\mathrm{mm}$ para a parede com continuidade e de 2,67 $\mathrm{mm}$ para a parede sem continuidade. Tais números, de qualquer forma, são muito próximos e, somente com base nesses dois ensaios, não é possível afirmar que há uma diferença significativa.

A diferença que se mostrou significativa é relativa ao surgimento de fissuras laterais nas extremidades do corpo de prova, quando aquecido somente em uma área de 1,20 m de comprimento, procurando-se simular uma continuidade como uma contenção lateral. O CP2 não apresentou fissura em sua face.

Tabela 6. Deslocamentos medidos nos ensaios.

\begin{tabular}{|c|c|c|c|c|c|c|}
\hline $\begin{array}{c}\text { Corpo } \\
\text { de } \\
\text { prova }\end{array}$ & $\begin{array}{c}\text { Flecha } \\
\text { para } \\
\text { face } \\
\text { externa } \\
\text { (mm) }\end{array}$ & $\begin{array}{c}\text { Flecha } \\
\text { para } \\
\text { a face } \\
\text { interna } \\
\text { (mm) }\end{array}$ & $\begin{array}{c}\text { Amplitude } \\
\text { das fechas } \\
(\mathrm{mm})\end{array}$ & $\begin{array}{c}\text { Amplitude } \\
\text { da variação } \\
\text { dimensional } \\
\text { (mm) }\end{array}$ & $\begin{array}{l}\text { Comprimento } \\
\text { do painel } \\
\text { radiante }(\mathrm{m})\end{array}$ & $\begin{array}{l}\text { Dilatação } \\
\text { ( } \mathrm{mm} / \mathrm{m}) \\
\text { em relação } \\
\text { à base de } \\
2,40 \mathrm{~m}\end{array}$ \\
\hline $\mathrm{CP} 1$ & $-2,45$ & 0,40 & 2,85 & 0,72 & 1,20 & 0,30 \\
\hline $\mathrm{CP} 2$ & $-1,97$ & 0,70 & 2,67 & 1,23 & $2,40^{*}$ & 0,51 \\
\hline
\end{tabular}

* dois painéis radiantes de 1,20 m cada um, colocados lado a lado.

\subsubsection{Ensaios em Paredes Leves (steel frame)}

Também foram realizados outros dois ensaios em corpos de prova de paredes leves, semelhantes ao sistema tipo steel frame, com perfis leves de aço galvanizado, como estrutura e chapas leves de fechamento. Os ensaios realizados com paredes do sistema leve visam comparar dois diferentes 
tipos de contenção. No primeiro, a variação dimensional do corpo de prova (CP3) foi bloqueada pela inserção de elementos de contenção lateral não pertencentes ao sistema construtivo (perfis metálicos de rigidez muito maior que o $\mathrm{CP}$ ). No segundo corpo de prova (CP4), foi mantida a contenção formada pela continuidade do próprio corpo de prova.

O CP3 era constituído por quadro estrutural de steel frame (perfis de $90 \mathrm{~mm} \times 40 \mathrm{~mm} \times 0,8 \mathrm{~mm}$ ) revestido por placas de fibrocimento na face externa e chapas de gesso para drywall na face interna. A dimensão do corpo de prova era de 1,20 m de comprimento por 2,40 m de altura. O CP4 também era constituído por quadro estrutural de steel frame (perfis de $90 \mathrm{~mm} \times 40 \mathrm{~mm} \times 0,8 \mathrm{~mm}$ ) revestido por placas de fibrocimento na face externa e chapas de gesso para drywall na face interna; todavia, sua dimensão era de 2,40 m de comprimento por 2,40 m de altura (Foto 11).
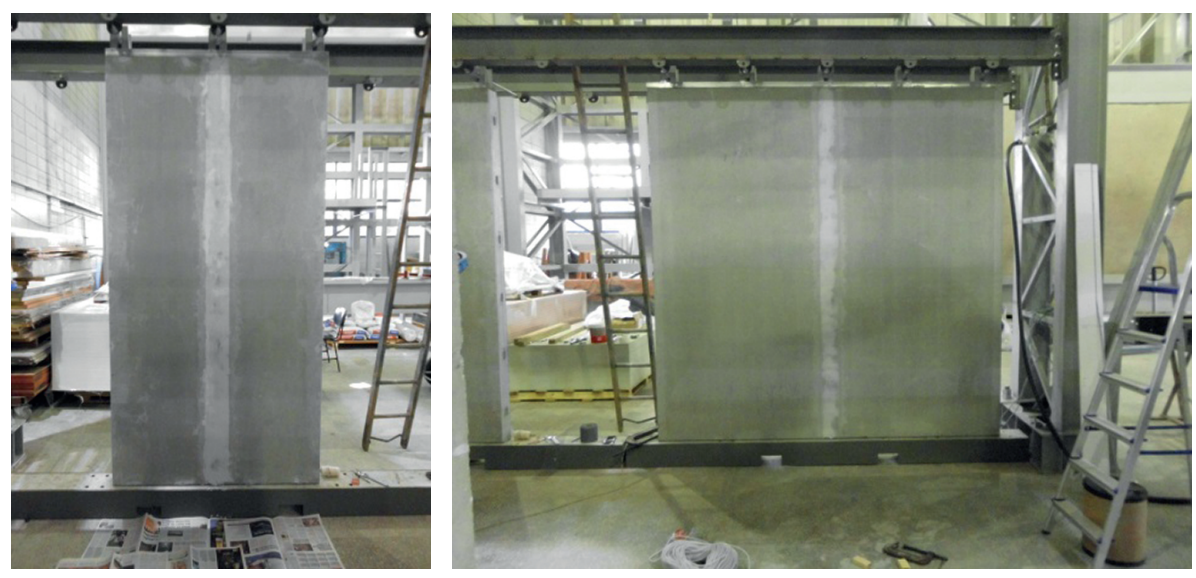

Foto 11. CP3 $(1,20 \mathrm{~m} \times 2,40 \mathrm{~m})$ e CP4 $(2,40 \mathrm{~m} \times 2,40 \mathrm{~m})$ com juntas típicas entre placas.

A base dos corpos de prova foi vinculada a uma viga de aço preenchida com concreto, com chumbadores, e seu topo foi fixado a cada montando, de forma a simular as condiçóes previstas em projeto e as condiçóes de uso (Foto12). 

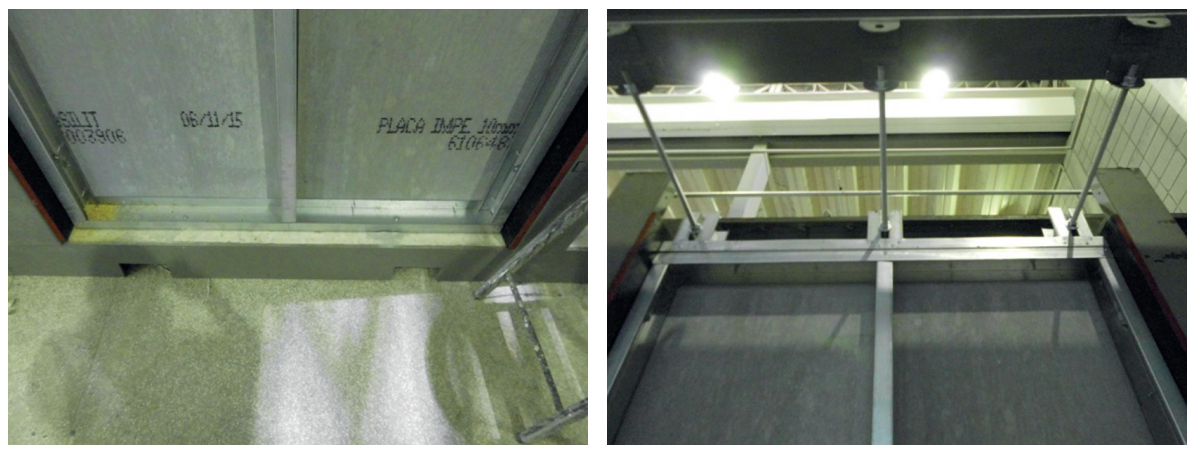

Foto 12. fixação da base e borda superior do CP-03.

No caso do CP3, foi adotado um sistema físico de vinculação lateral, com duas colunas de aço, de forma a permitir movimentaçôes parciais do corpo de prova, particularmente na direção perpendicular ao seu plano (Foto 13).

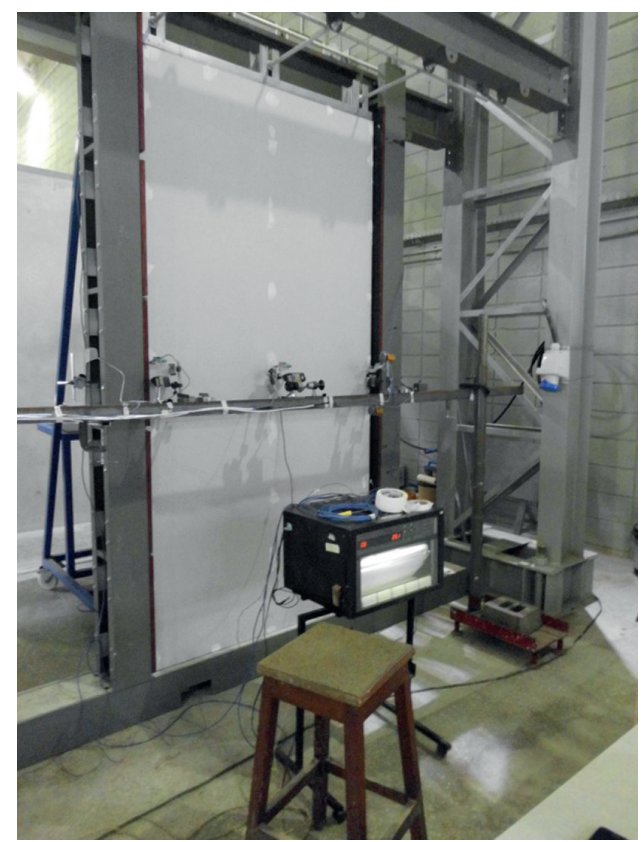

Foto 13. Vista da face interna do CP-03 com a placa de drywall e as colunas de contenção lateral. 
No caso do CP3, a área de exposição à fonte radiante foi de 1,20 m $\times$ 2,40 m, ou seja, toda a face do corpo de prova. A distância do painel radiante à face do corpo de prova foi de $28 \mathrm{~cm}$. A faixa de aspersão de água também abrangeu todo o comprimento do corpo de prova, de $1,20 \mathrm{~m}$, tendo sido observada uma distância dos bicos aspersores à face do corpo de prova de $40 \mathrm{~cm}$. No caso do CP4, de 2,40m de comprimento, a área de exposição à fonte radiante foi de 1,20 $\mathrm{m}$ de comprimento por 2,40 $\mathrm{m}$ de altura, com alinhamento do eixo da parede com o eixo do painel radiante, restando duas laterais com $60 \mathrm{~cm}$ de cada lado sem exposição direta. A distância do painel radiante à face do corpo de prova também foi de $28 \mathrm{~cm}$, tendo sido observado um comprimento total da aspersão da ordem de 1,40 m. Os bicos aspersores também ficaram a uma distância, da face do corpo de prova, de $40 \mathrm{~cm}$.

Observou-se que as medidas tomadas no CP3 resultaram em deslocamentos específicos horizontais, no plano da parede, até superiores àqueles constatados para o $\mathrm{CP} 4$, apesar de resultarem em deslocamentos absolutos menores. Para explicar esse fator, haveria a necessidade de realização de mais um ensaio, considerando sistema de travamento lateral e corpo de prova com 2,40 m, com painel radiante de 2,40 m.

$\mathrm{Na}$ Tabela 7, são apresentados os valores máximos absolutos observados para as flechas, ou seja, para os deslocamentos horizontais, no centro da parede.

Tabela 7. Variação da flecha no cento da parede.

\begin{tabular}{cccc}
\hline Corpo de Prova & Mínimo $(\mathbf{m m})$ & Máximo $(\mathbf{m m})$ & Amplitude $(\mathbf{m m})$ \\
\hline CP-3 & $-1,01$ & 1,51 & 2,53 \\
\hline CP-4 & $-0,97$ & 2,29 & 3,34 \\
\hline
\end{tabular}

Comparando-se a flecha obtida nos corpos de prova, verifica-se uma flecha maior no sistema com continuidade da parede - com amplitude 32\% maior em relação ao sistema com travamento lateral-, considerando-se os valores limites observados. Esse resultado pode por em questionamento a mobilidade pretendida com o sistema físico de travamento. Por outro lado, conforme pode ser verificado na Tabela 8 , as flechas apresentadas nos limites do aquecimento são menos diferentes entre as duas situaçóes. De qualquer 
forma, ainda observa-se uma restrição à movimentação para o sistema de travamento físico.

Tabela 8. Flechas apresentadas no limite lateral na projeção da radiação.

\begin{tabular}{ccccccc}
\hline \multirow{2}{*}{$\begin{array}{c}\text { Corpo de } \\
\text { Prova }\end{array}$} & $\begin{array}{c}\text { Mínimo } \\
(\mathbf{m m})\end{array}$ & $\begin{array}{c}\text { Máximo } \\
(\mathbf{m m})\end{array}$ & $\begin{array}{c}\text { Amplitude } \\
\mathbf{( m m})\end{array}$ & $\begin{array}{c}\text { Mínimo } \\
(\mathbf{m m})\end{array}$ & $\begin{array}{c}\text { Máximo } \\
(\mathbf{m m})\end{array}$ & $\begin{array}{c}\text { Amplitude } \\
(\mathbf{m m})\end{array}$ \\
\hline CP3 & $-0,37$ & 0,55 & 0,92 & $-0,49$ & 0,81 & 1,30 \\
\hline CP4 & $-0,18$ & 1,06 & 1,29 & $-0,35$ & 1,10 & 1,56 \\
\hline
\end{tabular}

A forma de se executar a contenção lateral do corpo de prova é um fator que pode impactar os resultados dos ensaios e dificultar a sua reprodutibilidade, dado que os valores dos deslocamentos são da ordem de milímetros, ou até de décimos de milímetros em algumas situaçóes. Logo, imprecisóes na sua execução podem causar desvios que já atinjam essa ordem de grandeza. Os ensaios realizados permitiram concluir que o uso uma continuidade do SVVE como contenção lateral gera menores riscos de variabilidade decorrente de execução, pois se trata do mesmo sistema construtivo, sem introduzir nenhum elemento exógeno.

Observa-se que, obviamente, a realização de ensaios reproduzindo todas as condiçôes de execução em obra, com suas dimensões e vínculos representados no corpo de prova, seria a condiçâo ideal. Isso, contudo, é muito difícil de viabilizar no dia a dia das avaliações de desempenho, além do que poderia onerar demais o ensaio.

\section{Proposta de Aprimoramento do Ensaio de Choque Térmico}

\subsection{Temperatura Superficial Limite}

Com base nos resultados das simulaçóes computacionais apresentadas no item 6.1, foram estabelecidos valores da temperatura de patamar ( $\mathrm{Tp}$ ) da face da parede no intuito de realizar o ensaio de choque térmico para três intervalos de valores da capacidade térmica externa das paredes, como indicado na Tabela 9. 
Tabela 9. Temperaturas de patamar para o ensaio, em função da capacidade térmica externa e da cor da face externa do SVE.

\begin{tabular}{|c|c|c|}
\hline \multirow[b]{2}{*}{$\begin{array}{l}\text { Capacidade térmica } \\
\text { externa da parede } \\
\qquad \mathbf{k J} /\left(\mathbf{m}^{2} . K\right)\end{array}$} & \multicolumn{2}{|c|}{ Cor da face do SVVE exposta ao clima } \\
\hline & $\begin{array}{l}\text { Cor média = clara } \\
\text { envelhecida (absortância de } \\
\text { aproximadamente } \mathbf{0 , 5} \text { ) }\end{array}$ & $\begin{array}{c}\text { Cor escura = média } \\
\text { envelhecida (absortância } \\
\text { de aproximadamente } 0,9 \text { ) }\end{array}$ \\
\hline Até 100 & $60^{\circ} \mathrm{C}$ & $80^{\circ} \mathrm{C}$ \\
\hline 101 a 200 & $55^{\circ} \mathrm{C}$ & $70^{\circ} \mathrm{C}$ \\
\hline Acima de 200 & $50^{\circ} \mathrm{C}$ & $65^{\circ} \mathrm{C}$ \\
\hline
\end{tabular}

Tais faixas foram definidas considerando-se todas as análises realizadas, observando-se os seguintes princípios: adoção de valores mais elevados de absortância à radiação solar, haja vista não haver controle sobre a cor das fachadas e sobre o grau de sujidade; adoção de margem de segurança em relação aos valores obtidos na simulação computacional, uma vez que se trata de ensaio acelerado e de poucos ciclos de ensaio, no caso dez ciclos.

A recomendação geral é que o ensaio seja feito considerando-se a temperatura de patamar na condição mais rigorosa, ou seja, para absortância à radiação solar de 0,9 . Admite-se a condição de menor absortância, no caso 0,5 , na qual a temperatura de patamar é reduzida, apenas nos casos em que haja recomendação explícita do emprego de cores claras, ou no caso do emprego de revestimentos exteriores naturalmente ou obrigatoriamente de cores claras.

\subsection{Taxa de Elevação da Temperatura Superficial}

Com base na ETAG 004 (EOTA, 2008) e nos ensaios realizados tanto especificamente para esse estudo como anteriormente, no dia a dia do Laboratório de Componentes e Sistemas Construtivos do IPT, propóe-se a adoção de um tempo mínimo de aquecimento de uma hora para atingir a temperatura de patamar, a fim de se evitar o surgimento de tensóes térmicas irreais. A exequibilidade física desse requisito é de baixa complexidade, bastando controlar a radiação fornecida. 


\subsection{Controle dos Parâmetros do Fluxo de Água de Resfriamento}

A proposta de aprimoramento do método contempla a adoção vazão de água de aspersão $3 \mathrm{~L} /\left(\mathrm{m}^{2} . \mathrm{min}\right)$, que, se é bem maior que o das normas internacionais, é o mesmo adotado no ensaio de estanqueidade à água de fachadas, contida no critério de estanqueidade à água de chuva, em SVVE, da NBR 15575-4 (ABNT, 2013).

Definiu-se também a temperatura da água em $15^{\circ} \mathrm{C} \pm 2^{\circ} \mathrm{C}$. Chegou-se a esse valor de temperatura pela análise das temperaturas de ponto de orvalho nas cidades brasileiras consideradas mais críticas. A temperatura das gotas de chuva tende a esses valores conforme elas deslocam em direção ao solo.

Além disso, fixou-se o tempo de aspersão em uma hora, de forma a padronizar o período de resfriamento. A análise de resultados históricos do IPT indicou que, independentemente da massa da parede, esse é o tempo para que sua face externa chegue à temperatura ambiente. Aqui, considerando-se aspectos ambientais, no que se refere à redução do consumo de água, sugere-se a implantação de um sistema de reaproveitamento da água utilizada no ensaio.

\subsection{Tolerâncias entre Valores de Temperaturas da Face da Parede (Diferenças entre Centro e Bordas)}

A proposta consiste em continuar a se utilizar apenas a temperatura do ponto central do corpo de prova como referência para controle do ensaio. A tolerância para esse ponto central deve ser mantida no mesmo valor da norma atual, ou seja, $\pm 3^{\circ} \mathrm{C}$, que é compatível com a normalização internacional e exequível operacionalmente.

Para as temperaturas dos pontos da borda, considera-se a definição de uma tolerância relativa à temperatura do ponto central como a mais coerente com a variaçáo proporcionada por um painel radiante de dimensóes semelhantes ao corpo de prova, mas com um valor de tolerância menor do que a definida pela ISO 8336 (ISO, 2009), porém, maior do que a especificada hoje na NBR 15575 (ABNT, 2013), definida com base no que foi observado seja do projeto de pesquisa, seja em outros trabalhos prestados pelo IPT. Deste modo, propóe-se que para os quatro pontos de borda seja tolerada uma variação de $\pm 6^{\circ} \mathrm{C}$. 


\subsection{Dimensões e Contenção Lateral dos Corpos de Provas}

Os resultados obtidos até o momento demonstram que a "contenção lateral" proporcionada por uma continuidade não aquecida da parede pode ser uma alternativa viável para a imposição de restriçóes à movimentação lateral. As diferenças observadas nos ensaios realizados considerando as duas opções de vinculação foram pouco significativas com relação aos deslocamentos horizontais apresentados pelos corpos de prova, apesar dos maiores deslocamentos em corpos de prova com dimensão maior. Isso é um dado relevante, visto que existia o receio de que as laterais pudessem estar oferecendo resistência ao deslocamento horizontal.

Também é importante ressaltar a possibilidade da introdução de vinculaçóes no corpo de prova, simulando as condiçóes de uso, tanto na base como no topo. Tais vinculaçóes já criam condiçôes no corpo de prova, que permitem contençóes internas, de forma semelhante às empregadas em obra. Seria uma dificuldade muito grande garantir que laboratórios diversos pudessem desenvolver sistemas físicos de travamento lateral, que pudessem ter desempenho equivalente, a menos que se reproduzissem as condiçóes de uso, nas dimensóes reais.

Todavia, há que se avaliar a questão das fissuras ocorridas em um dos corpos de prova, quando é aquecido apenas um trecho da parede. Como essas fissuras ocorrem na zona de "continuidade", deve-se discutir se é possível ou não ser considerada para efeito da avaliação técnica.

Resumindo-se, são feitas as seguintes sugestóes:

- Adoção de corpo de prova de pelo menos 2,40 m de comprimento, considerando-se um painel radiante de $1,20 \mathrm{~m}$ de comprimento. Como recomendação geral, o corpo de prova deve ter comprimento equivalente ao dobro do comprimento do painel radiante, de forma a resultar $1 / 4$ de continuidade para cada lado do corpo de prova. A critério da Instituição Avaliadora, em razão de características específicas do sistema construtivo a ser avaliado, poderia ser adotado, por exemplo, um corpo de prova de $4,80 \mathrm{~m}$ de comprimento, com painel radiante de 2,40 m (ou dois de 1,20 m lado a lado);

- Adoção ou simulação de detalhes típicos do sistema construtivo na base e no topo do corpo de prova;

- Adoção dos detalhes típicos existentes nas paredes de fachada, como revestimentos, juntas, interfaces com revestimentos internos, etc. É fundamental a execução de juntas, quando presentes no sistema construtivo. 
Neste particular, um corpo de prova com 2,40 m de comprimento é mais representativo do sistema construtivo que a situação atual de 1,20 m; até mesmo, se necessário, corpos de prova com dimensóes maiores;

- Adoção de corpo de prova com altura equivalente ao pé direito, nas situações comuns de uso do sistema construtivo: A altura do painel radiante deverá ser compatível com a altura do corpo de prova.

\subsection{Consolidação dos Aprimoramentos Propostos}

Os aprimoramentos aqui apresentados podem oferecer uma contribuição significativa para uma melhor padronizaçáo do ensaio, proporcionando uma maior reprodutibilidade e repetitividade. Com o estabelecimento de especificaçóes e limites para um maior número de parâmetros, pretende-se reduzir eventuais variaçóes nos procedimentos de realização do ensaio entre laboratórios ou instituições diferentes.

Nesse contexto e com base nos resultados e análises apresentados, propóe-se a adoção dos parâmetros apresentados na Tabela 10 para efeito do aprimoramento do método de ensaio de ACCT, em relação ao atual previsto na NBR 15575-4 (ABNT, 2013).

Tabela 10. Temperaturas de referência para o ensaio.

\begin{tabular}{|c|c|c|}
\hline Item & $\begin{array}{l}\text { NBR 15575-4 } \\
\text { (ABNT, 2013) }\end{array}$ & Proposta \\
\hline $\begin{array}{l}\text { Temperatura a ser usada } \\
\text { como referência para } \\
\text { controle do ensaio }\end{array}$ & Não definido & Ponto central \\
\hline $\begin{array}{l}\text { Temperatura superficiais } \\
\text { limites - Temperatura de } \\
\text { patamar a ser obtida no } \\
\text { centro do corpo de prova. }\end{array}$ & $(80 \pm 3)^{\circ} \mathrm{C}$ & $\begin{array}{c}(80 \pm 3)^{\circ} \mathrm{C}, \mathrm{p} / \mathrm{CTe} \leq 100 \mathrm{~kJ} /\left(\mathrm{m}^{2} . \mathrm{K}\right) \\
(70 \pm 3)^{\circ} \mathrm{C}, \mathrm{p} / 100<\mathrm{CTe} \leq 200 \mathrm{~kJ} /\left(\mathrm{m}^{2} . \mathrm{K}\right) \\
(65 \pm 3)^{\circ} \mathrm{C}, \mathrm{p} / \mathrm{CTe}>200 \mathrm{~kJ} /\left(\mathrm{m}^{2} . \mathrm{K}\right) \\
\text { NOTA: No caso de restrições para } \\
\text { cores claras da fachada, os limites de } \\
\text { temperatura são, respectivamente, de } \\
60^{\circ} \mathrm{C}, 55^{\circ} \mathrm{C} \text { e } 50^{\circ} \mathrm{C}, \text { com tolerância } \\
\text { de } \pm 3^{\circ} \mathrm{C} \text {. }\end{array}$ \\
\hline $\begin{array}{c}\text { Taxa de elevação da } \\
\text { temperatura superficial }\end{array}$ & $\begin{array}{c}\text { Sem } \\
\text { especificação }\end{array}$ & Tempo mínimo de 1 hora \\
\hline $\begin{array}{l}\text { Tempo de permanência na } \\
\text { temperatura limite (máxima) }\end{array}$ & $1 \mathrm{~h}$ & $1 \mathrm{~h}$ \\
\hline
\end{tabular}

* Mais pontos de medição de temperatura podem ser utilizados para alguma condição de pesquisa, como 1 posicionado no centro da na face interna (oposta ao aquecimento) do SVVE. 
Tabela 10. Continuação.

\begin{tabular}{|c|c|c|}
\hline Item & $\begin{array}{l}\text { NBR 15575-4 } \\
\text { (ABNT, 2013) }\end{array}$ & Proposta \\
\hline $\begin{array}{l}\mathrm{N}^{\circ} \text { de pontos de } \\
\text { registro temperatura }\end{array}$ & 5 & $5^{*}$ \\
\hline $\begin{array}{l}\text { Localização dos pontos de } \\
\text { registro das temperaturas na } \\
\text { face do aquecimento. }\end{array}$ & $\begin{array}{l}1 \text { central; e } \\
4 \text { periféricos }\end{array}$ & 1 central; e 4 periféricos* \\
\hline $\begin{array}{c}\text { Tolerância para a temperatura } \\
\text { dos pontos de boras }\end{array}$ & $\pm 3^{\circ} \mathrm{C}$ & $\pm 6^{\circ} \mathrm{C}$ \\
\hline $\begin{array}{l}\text { Temperatura da } \\
\text { água de aspersão }\end{array}$ & $\begin{array}{c}\text { Sem } \\
\text { especificação }\end{array}$ & $15^{\circ} \mathrm{C} \pm 3^{\circ} \mathrm{C}$ \\
\hline Vazão da água de aspersão & $\begin{array}{c}\text { Sem } \\
\text { especificação }\end{array}$ & $3 \mathrm{~L} /\left(\mathrm{m}^{2} . \mathrm{min}\right)$ \\
\hline Tempo de aspersão de água & $\begin{array}{l}\text { Definido pela } \\
\text { temperatura } \\
\text { da face }\end{array}$ & 1 hora \\
\hline $\begin{array}{l}\text { Comprimento do } \\
\text { corpo de prova }\end{array}$ & $1,20 \mathrm{~m}$ & $\begin{array}{c}2,40 \mathrm{~m} \text { (dobro do comprimento } \\
\text { do painel radiante) }\end{array}$ \\
\hline $\begin{array}{l}\text { Contenção lateral } \\
\text { para sistemas leves }\end{array}$ & $\begin{array}{c}\text { Sem } \\
\text { especificação }\end{array}$ & $\begin{array}{l}\text { Dada pela continuidade } \\
\text { do corpo de prova }\end{array}$ \\
\hline Número de ciclos & 10 & 10 \\
\hline $\begin{array}{l}\text { Intervalo entre } \\
\text { um ciclo e outro }\end{array}$ & $\begin{array}{c}\text { Sem } \\
\text { especificação }\end{array}$ & $\begin{array}{l}24 \text { horas entre o início de um ciclo e } \\
\text { início do ciclo seguinte, no mínimo. }\end{array}$ \\
\hline
\end{tabular}

* Mais pontos de medição de temperatura podem ser utilizados para alguma condição de pesquisa, como 1 posicionado no centro da na face interna (oposta ao aquecimento) do SVVE.

A vinculação da temperatura superficial limite, da superfície exposta da parede, à sua capacidade térmica implica em uma adequação do método de ensaio às diversas tecnologias presentes no mercado, considerando a simulação das condições de exposição por meio de ensaios. Não seria possível deixar isso em aberto, ou seja, para que cada laboratório definisse uma temperatura de ensaio em função da capacidade térmica da parede, considerando uma curva contínua, pois poderia haver ainda diferenças significativas entre laboratórios. Por essa razão, está sendo proposta a consideração de três faixas distintas, em vez de uma condição única. Ressaltase que para a Capacidade Térmica Externa, no caso do emprego de núcleos isolantes térmicos na parede, considerou-se o cálculo do lado externo da parede, desprezando-se produtos ou materiais internos, após esse núcleo. Para que uma camada de material seja considerada isolante térmico, propóe-se 
adotar o mesmo critério já de consenso, de condutividade térmica menor ou igual a $0,065 \mathrm{~W} /(\mathrm{m} . \mathrm{K})$ e Resistência Térmica maior ou igual a $0,5 \mathrm{~m}^{2} . \mathrm{K} / \mathrm{W}$.

A padronização da temperatura da água, por sua vez, reduz as diferenças entre ensaios realizados em diversas épocas do ano ou por laboratórios localizados em cidades distintas, com climas distintos. No que se refere à vazão de água, considerou-se aquela já especificada no caso dos ensaios de estanqueidade à água de paredes externas.

A adoção de um gradiente para aquecimento, aqui denominado rampa de aquecimento, evita a ocorrência de mudanças ou elevaçóes bruscas de temperatura na fase de aquecimento. O choque térmico é o fator preponderante de mudança brusca de temperatura, admitindo ainda que a proposta que está sendo feita é a de considerar a temperatura da água constante em $15^{\circ} \mathrm{C}$, a qual é mais baixa que a atualmente adotada no método em vigor, como temperatura ambiente, que pode variar de laboratório para laboratório e entre regiôes do país.

A definição do ponto central de medida de temperatura como referência para o ensaio facilita a determinação do tempo de início de cada fase. As tolerâncias propostas para as variaçóes de temperatura, quer do mesmo ponto, quer entre ponto central e pontos de borda, abrangem vários sistemas construtivos, desde que o ensaio seja realizado em um ambiente coberto e fechado, abrigado de correntes de ar.

A adoção de corpo de prova com maior comprimento visa simular uma continuidade da parede, que poderia proporcionar restriçóes às movimentaçôes da parede, por efeito de temperatura e umidade.

O próximo passo é incorporar tais parâmetros ao método de ensaio, ou seja, propor um método de ensaio aprimorado pela rede de pesquisas, de forma que possa ser discutido pela sociedade e, eventualmente, incorporado à NBR 15575-4, em uma próxima revisão. Trata-se de uma importante contribuição desta rede de pesquisa à sociedade brasileira, na avaliação de aspectos de durabilidade de sistemas construtivos para a construção de habitaçôes.

Finalmente, ressalta-se que os resultados decorrentes do método de ensaio são relevantes para identificar a possibilidade de ocorrência de problemas em fachadas, visto que, nas situaçóes nas quais se detectam problemas no ensaio, geralmente ocorrem falhas nas edificaçôes. Entretanto, 
mesmo quando não há problemas no ensaio, seus resultados podem não ser suficientes para garantir que a fachada tenha desempenho adequado, havendo necessidade de análises complementares, especialmente quando as condições da obra são bem diferentes das empregadas nos ensaios.

\section{Referências}

ASSOCIAÇÃO BRASILEIRA DE NORMAS TÉCNICAS - ABNT. NBR 15220: Desempenho Térmico de Edificaçóes. Rio de Janeiro, 2008.

ASSOCIAÇÃO BRASILEIRA DE NORMAS TÉCNICAS - ABNT. NBR 15575-4: Desempenho parte 4: Requisitos para sistemas de vedaçóes verticais internas e externas SVVIE. Rio de Janeiro, 2013.

AMERICAN SOCIETY FOR TESTING AND MATERIALS - ASTM. ASTM C 1185: Standard Test Methods for Sampling and Testing Non-Asbestos Fiber-Cement Flat Sheet, Roofing and Siding Shingles, and Clapboards. Pennsylvania, EUA, 2008.

AUSTRALIAN/NEW ZEALAND STANDARD. AZ NZS 2908-2: Cellulose-cement products Part 2: Flat sheets. AUSTRALIA, 2000

EUROPEAN ORGANIZATION FOR TECHINCAL APPROVALS - EOTA. ETAG 004: Guideline for European Technical Approval of External Thermal Insulation Composite System with Rendering. Bruxelas, 2008.

KREITH, F.; BOHN, R.M.M. Princípios de Transferência de Calor. Pioneira Thomson Learning, 2003.

FONTENELLE, J.H.; MITIDIERI FILHO, C.V. Condiçôes de contorno dos corpos de prova submetidos ao ensaio de ação de calor e choque térmico. Anais... ENTAC, 2016.

INTERNATIONAL ORGANIZATION FOR STANDARDIZATION - ISO. ISO 8336. Fiber-cement flat sheets. Product specification and test metholds. Suíça, 2009.

LORENZI, L.S. Análise crítica e proposiçóes de avanço nas metodologias de ensaios experimentais de desempenho à luz da ABNT NBR 15575 (2013) para edificaçóes habitacionais de interesse social térreas. Dissertação (MEstrado) - UFRGS, 245p. Porto Alegre. 2015. Disponível em: http://www.lume.ufrgs.br/handle/10183/96630?locale=pt_ BR

OLIVEIRA, L.A.; FONTENELLE, J.H.; MITIDIERI FILHO, C.V. Durabilidade de fachadas: método de ensaio para verificação da resistência à ação de calor e choque térmico, in Revista Ambiente Construído. Porto Alegre. ANTAC, 2014. Disponível em: http://www.seer.ufrgs.br/ambienteconstruido/article/view/45672 